\title{
Hide seek and negotiate: Alfred Cope and counter intelligence in Ireland 1919-1921
}

Article

Accepted Version

Sloan, G. (2018) Hide seek and negotiate: Alfred Cope and counter intelligence in Ireland 1919-1921. Intelligence and National Security, 33 (2). pp. 176-195. ISSN 1743-9019 doi: https://doi.org/10.1080/02684527.2017.1329118 Available at https://centaur.reading.ac.uk/67484/

It is advisable to refer to the publisher's version if you intend to cite from the work. See Guidance on citing.

To link to this article DOI: http://dx.doi.org/10.1080/02684527.2017.1329118

Publisher: Taylor \& Francis

All outputs in CentAUR are protected by Intellectual Property Rights law, including copyright law. Copyright and IPR is retained by the creators or other copyright holders. Terms and conditions for use of this material are defined in the End User Agreement.

\section{www.reading.ac.uk/centaur}

\section{CentAUR}

Central Archive at the University of Reading

Reading's research outputs online 
HIDE SEEK AND NEGOTIATE: ALFRED COPE AND COUNTER INTELLIGENCE IN IRELAND 1919-1921

The negotiations which he (Cope) undertook at considerable danger to himself were approved by his superiors and he was able to bring about a state of affairs whereby the treaty of 1921 could be signed. ${ }^{1}$

I do not know if anything can be done to restrain persons like Mr Cope from preaching rebel doctrines in this Brigade Area. The area administered by the Essex Regiment is a bad one, and the rebels were only kept from over-running the whole area by the good military spirit shown by this regiment. ${ }^{2}$

Perhaps it is true of Andy (Alfred Cope) as it is of most of those who have had to make their own way to make, and have made it, that he clings to power won against the odds more jealously then men to whom power has come without great effort. ${ }^{3}$

\section{INTRODUCTION}

These three epigraphs illustrate both the personality and the actions of the Englishman Alfred 'Andy' Cope who, between 1920 and 1922, held the post of Assistant under Secretary in Dublin Castle, with specific responsibility for police administration and efficiency,then the centre of British administration in Ireland. This was a period when the United Kingdom of Great Britain and Ireland was engaged in fighting an insurgency inside its borders. Foot has chronicled his career before his posting to Ireland ${ }^{4}$. He has also suggested the nature of Cope's activities with respect to the leaders of this insurgency: "After several false starts, he secured the confidence of the principle Irish revolutionary leaders, Michael Collins, Arthur Griffith and Eamon de Valera, in his own good faith, while remaining perfectly loyal to the crown.... and he played a major part in securing the truce of 11 July 1921"5. Foot also revealed on

\footnotetext{
1 The Times 14th May 1954.

${ }^{2}$ Memo by Colonel Commandant $17^{\text {th }}$ Infantry Brigade to Headquarters $6^{\text {th }}$ Division, Ireland $15^{\text {th }}$ September 1921.Strickland Papers ,Imperial War Museum P363.

${ }^{3}$ The Last Days of Dublin Castle, The Diaries of Mark Sturgis,(ed M. Hopkinson) Dublin: Irish Academic Press 1999 ,p42.

${ }^{4}$ Alfred William Cope was born in 1877 and entered government service as a boy clerk. He joined the detective branch of the department of customs and excise in 1896 ; and was made a preventative inspector in 1908.His energy and intelligence soon made him head of the branch in London and he spent ten adventurous years pursuing smugglers and illicit distillers, especially in the docklands." M. R. D. Foot, Dictionary of National Biography 1951-1960 ,Oxford :Oxford University Press,1971 p251. ${ }^{5}$ Ibid p 252.
} 
whose authority he was acting: "Ostensibly his task was to preserve civil order through the Royal Irish Constabulary; in fact he had already been charged by Lloyd George with the task of sounding out Sinn Fein opinion about the possibilities of a truce in the Anglo-Irish war" ${ }^{6}$ Hopkinson has endorsed this judgement: "He became, probably at Lloyd George's wish, the main British contact with Sinn Fein and the IRA and set up a host of peace initiatives, nervy and highly strung by temperament, Cope was intensely hard working but seemed unable to delegate". ${ }^{7}$ His activities during this period are critical to understand as they go far to explain the outcome of the insurgency. However, this is hampered by two things: "The secretive character of Cope's work and the absence of personal papers make him a tantalisingly enigmatic figure". ${ }^{8}$ Most of the existing literature, with the exception of the diaries of Mark Sturgis, which contain both oblique and candid references to Cope's activities, ${ }^{9}$ support a teleological narrative that he was carrying out a policy formulated by Lloyd George and enacted by a small group of civil servants in Dublin Castle.

This article will address the unquestioned impediments indicated by Hopkinson in a two-fold manner. First, by framing the empirical evidence of his activities, between June 1920 and the October 1922 with a counter-intelligence analysis. Dulles defined counter-intelligence in the following manner: "Counter-espionage is inherently a protective and defensive operation. Its primary purpose is to thwart espionage against one's country, but it may also be extremely useful in uncovering hostile penetration and subversive plots." 10 The perennial concepts or variables of counter-intelligence are to 'locate, identify and neutralize'. Zuehlke developed a more nuanced approach when he argued that there was an essential corollary to any counter- intelligence activity. He described it as 'counter-intelligence information' ${ }^{11}$ His point was that these three variables oversimplify a complex reality. He cited Sherman Kent because he : "shows an awareness of this vital feature by mentioning 'the knowledge and the activity' that must precede action taken against the

\footnotetext{
${ }^{6}$ Ibid p252.

${ }^{7}$ The Last Days of Dublin Castle, The Diaries of Mark Sturgis (ed M. Hopkinson) Dublin :Irish Academic Press ,1998 p5-6.

${ }^{8}$ Ibid p6.

${ }^{9}$ Mark Sturgis was a British civil servant from the Treasury who was appointed joint Assistant Secretary along with Cope in May 1920.Interestingly he was not gazetted in that position until after the truce in July 1921.His diaries which he kept of this period were published in 1998. They will be used in this article. However, he was careful to limit any specific references to Cope's contacts to the leaders of Sinn Fein.

${ }^{10}$ A. Dulles ,The Craft of Intelligence, London Weidenfeld and Nicolson ,1963p122.

${ }^{11}$ A.A. Zuehike, What is Counter-intelligence? From Intelligence Requirements for the 1980's(ed

R.Godson) London: Transaction Books, 1980,.p15.
} 
threat. He is alluding to the process of gathering, compiling, analyzing, and using CI information to support the countering operation." 12

The question is to what extent do counter-intelligence concepts such as gathering, compiling and analyzing secret information provide some explanatory power to understand Cope's activities in Ireland between 1920 and 1921? There are also a number of associated questions which will be addressed. To what extent did his relationship with the leaders of the insurgency facilitate a British Government decision to progressively grant de facto legal immunity to the leaders of the insurgency? Did he systematically pass confidential information; including secret communication ciphers that endangered the lives of members of the Royal Irish Constabulary and undermined the effectiveness of police operations against the IRA? It is important to acknowledge that identifying the key cause of something is not straightforward and needs careful qualification. As Lewis has argued:"When we claim to have identified 'the cause of something' we are really making a claim about which part of the causal history is most salient for the purposes of some particular inquiry." 13

To answer these questions it is necessary to make an assessment of the nature of the intelligence organisations that existed prior to 1919.In addition, an assessment of the efficacy of the new intelligence organisations that were set up in Ireland from 1920 onwards is also needed. It will be argued that British intelligence community in Ireland located and identified accurately Cope's developing relationship with the leaders of the insurgency. However, his activities proved impervious to any countering operation. Therefore both process and product are important.

How do we judge the effectiveness of intelligence during this period? There is the challenge of understanding the nature of intelligence itself. Laqueur summarised it in the following way: "On the one hand it (intelligence) refers to an organisation collecting information and on the other to the information that has been gathered." 14 Sherman Kent interpreted intelligence as both 'a process and an end -product'. In addition, he developed the hypothesis that intelligence activity consists of two sorts of operation: "I have called them the surveillance operation, by which I mean the many ways by which the contemporary world is put

\footnotetext{
${ }^{12}$ Ibid p15.

${ }^{13}$ D. Lewis. (check reference)

${ }^{14}$ Quoted in C. Andrew, R.J.Aldrich and W.K. Wark(eds) Secret Intelligence :A Reader, Abingdon:Routledge ,2009 p6.
} 
under close and systematic observation, and the research operation. By the latter I mean the attempts to establish meaningful patterns out of what was observed in the past and attempts to get meaning out of what appears to be going on now." 15

David Kahn's historical theory of intelligence draws attention to the extent that intelligence optimises resources. ${ }^{16}$ One of the accepted judgements about the insurgency during this period was that the intelligence resources of the British state did not have any tangible effect on the insurgency: "Neither the Army nor the police were able to build the essential foundation for success in guerrilla warfare, a dependable intelligence service." 17 Townshend fails to comment on one important dimension: a new intelligence community was created in the midst of an insurgency. Hart has argued that, the 'nearly unanimous' verdict on both the intelligence process and the end product has been as follows : 'British intelligence' out-witted and out-spied -emerges from most accounts of the revolution as a contradiction in terms: a disastrous compound of misdirection, malice and ignorance." 18

This judgement runs like a golden thread through the published work on the intelligence aspect of the insurgency. There is a near universal disparagement of British intelligence in Ireland . O'Halpin has argued that: "intelligence activity after this (the murder of Alan Bell) ${ }^{19}$ was largely the preserve of organisations outside the direct control of the Castle authorities and of the conventional police, a situation which frequently produced chaos." ${ }^{20}$ Andrew has condemned the whole period from 1916 to 1921 as an 'Irish debacle' ${ }^{21}$.In his account of the period 1920-1921, Cope is not mentioned once. Porch claimed that: "London's security services were poorly positioned to deal with growing Irish unrest." 22 Foster has cited intelligence as the key force multiplier that made coherent all dimensions of the IRA's efforts: "the diverse strategies of the IRA were linked by Collin's legendary intelligence network, often

\footnotetext{
${ }^{15}$ S. Kent, Strategic Intelligence for American World Policy, 1965 p4 (finish details)

${ }^{16}$ See D. Kahn ,An Historical Theory of Intelligence ,from P. Gill, S. Marrin, and M. Phythian, Intelligence Theory, Key Questions and Debates ,Abingdon :Routledge,2009 p 4-15.

${ }^{17}$ C. Townshend, The British Campaign In Ireland 1919-1921, Oxford: Oxford University Press $1975, \mathrm{p} 205$.

${ }^{18}$ P. Hart (ed)British Intelligence in Ireland ,1920 -1921: The Final Reports ,Cork :Cork University press ,2002 p1

${ }^{19}$ Bell was a high ranking British civil servant who was murdered by the IRA in Dublin in March 1920.He was investigating their sources of funding.

${ }^{20}$ E. O’Halpin, The Decline of the Union, Dublin: Gill \& Macmillan,1987.p199.

${ }^{21}$ C. Andrew, Secret Service, The Making of the British Intelligence Community, London: Spectre Books , 1986 pp354-372.

${ }^{22}$ D. Porch, Counterinsurgency: Exposing the Myths of the New War,Cambridge :Cambridge University Press ,2013 p114.
} 
utilizing individuals in a fairly high walk of life who openly boasted of their British connection." ${ }^{23}$ Foy's gave a more nuanced argument, although still in the slipstream of the dominant narrative. Critically, unlike most of the other accounts, he placed intelligence in its political context: "As events in Ireland demonstrated, intelligence can go a long way to denying victory. Ultimately the fault on the British side lay not in a dysfunctional and muddled intelligence system or personal inadequacies but with the politicians at the top. Indeed politicians caused many of the problems with which British intelligence officers had to grapple". ${ }^{24}$ Foy's assertion is right, as an understanding of the real political context intelligence organisations were having to operate in is crucial. It is only when this is understood that a degree of clarity can be given to two things. First what were the objectives that a small number of senior Dublin Castle civil servants and the Prime Minister working to? Secondly, the veracity of the assertion made by Paul Bew, that British intelligence operations in this period were designed principally to soften up the Sinn Fein leadership and make it more amenable will be challenged. ${ }^{25}$

This article will argue that Cope was more than just a negotiator on behalf of His Majesty's Government. It is intends to build on a series of judgements. Charles Townshend has claimed that Cope : "Working to secret instructions from Lloyd George, who often, in Cabinet, disowned his moves, Cope tirelessly struggled to establish common ground for negotiations. But his dedication in this sphere limited his success in other directions, especially the vital one of liaison with the Army "26 Peter Hart gave a different perspective and acknowledged that Cope's 'back-channel contacts' led to a progressive extension to the leaders of the insurgency of de facto legal immunity" ${ }^{27}$. General Macready who was GOC in Ireland between 1920 and 1922 provided a less generous judgement of Cope: "He was persona grata with the leaders of the rebellion, in whom he had a belief that was pathetic as, in my opinion, it was misplaced." 28

Related to these diverse judgements are the interpretations of the character of the conflict itself. Many senior British policy makers perceived the political violence merely as the product of a 'murder

\footnotetext{
${ }^{23}$ R.F.Foster,Modern Ireland 1600-1972,London :Penguin Books,1988 p500.

${ }^{24}$ M. Foy ,Michael Collin's Intelligence War, Stroud ;Sutton Publishing ,2006 p243.

${ }^{25}$ P. Bew, Moderate Nationalism and the Irish Revolution ,1916-1923,The Historical Journal Vol 42,3 1999 p745.

${ }^{26} \mathrm{C}$, Townshend, British Campaign in Ireland, Oxford :Oxford University Press, 1975 p80

${ }^{27}$ Hart Op Cit p15

${ }^{28}$ N. Macready, Annals of an Active Life Vol 2 , London: Hutchinson,1924 p493.
} 
gang. ${ }^{29}$ Some also interpreted the insurgency as 'an exceptional crime wave'. The British Army in 1921 evaluated it in the following way : "The situation in Ireland is partly guerrilla, partly rebellion, partly organized murder." 30 In February 1920 the RIC referred to the insurgency as," the guerrilla warfare of Sinn Fein. ${ }^{31}$ " Between 1919 and 1921 there was an insurgency in Ireland. O'Neill has outlined its dimensions as, a struggle between a non -ruling group and the ruling authorities in which the nonruling group consciously used political resources and violence to destroy, reformulate or sustain the basis of legitimacy of one or more aspects of politics. ${ }^{32}$

O'Neill's definition says nothing about the intelligence institutions that a state trying to counter this kind of violence needs to put in place.

Popplewell has argued that the primary responsibility must fall to the police: "Good police intelligence was at the heart of counter-insurgency. This alone could nip the trouble in the bud, and this alone could provide the army with the information necessary for effective operations against the insurgents." ${ }^{33}$ Frank Kitson, by contrast, developed a typology with respect to the varieties of intelligence that are required," the first sort of information might be described as political intelligence, and the second sort as operational intelligence". ${ }^{34}$ Keith Jeffrey formulated an alternative typology with respect to the intelligence required for anti-terrorist and counter-insurgency operations "background intelligence, operational intelligence, and criminal intelligence.It is the third type of intelligence which most outstandingly distinguishes the use of intelligence in 'low intensity' conflict from its use in a conventional war." ${ }^{35}$

In 1919 Ireland had two police forces the Dublin Metropolitan Police and the Royal Irish Constabulary. They both lacked an intelligence capability to effectively respond to the emerging insurgency. The reason for this is that their capability had been systematically attacked by the insurgents. Specifically, the ' $G$ ' Division of the Dublin Metropolitan Police, and the Crimes Special Branch of the Royal Irish Constabulary suffered sustained attrition. It was these circumstances that brought about two

\footnotetext{
${ }^{29}$ Lloyd George (finish off )

${ }^{30}$ Intelligence Conference ,October 1921,Grosvenor Hotel Chester, Foulkes Papers 7/21,Liddel Hart Military Archives ,King's College,London.

${ }^{31}$ Quoted in C. Townshend, The British Campaign in Ireland, Oxford :Oxford University Press, 1975pp55. $\mathrm{p}$

${ }^{32}$ B. O’Neill, Insurgency and Revolution :Revolution to Apocalypse, Washington DC: Potamac Books ,2005 p15.

${ }^{33}$ R. Popplewell. Lacking Intelligence: Reflections on Recent Approaches to British Counterinsurgency, Intelligence and National Security Vol 10, No2, 1995 p345. Some

${ }^{34}$ F. Kitson, Low Intensity Operations, London: Faber\& Faber, 1971 p72.

${ }^{35} \mathrm{~K}$. Jeffrey ,Intelligence and Counter-Insurgency Operations: Some Reflections on the British Experience, Intelligence and National Security Jan 1987 ,Vol 2, No 1 p141.
} 
important developments. First setting up of new all Ireland intelligence institutions to compensate for this intelligence deficit; secondly, the gradual involvement of the British Army in supporting the two police forces and the development of its own intelligence gathering structures that could both process intelligence and produce an end product. This article will not examine the British Army's intelligence structures in any great detail except when it enables a better understanding of Cope's activities. $^{36}$

\section{THE CONTEXT AND THE NEED}

On $21^{\text {st }}$ January 1919 in Dublin, a city that was an integral part of the United Kingdom of Great Britian and Ireland, an extreme nationalist organisation- Sinn Fein made a unilateral declaration of independence. ${ }^{37}$ This event took place in the Round Room of Dublin's Mansion House. The Times commented:"The whole thing is, of course, childishly illegal." 38.It was UDI was rooted in the context of the 'other': "Whereas English rule in this country is, and always has been, based on force and fraud and maintained by military occupation against the declared will of the people". ${ }^{39}$ Alongside this declaration there was a message to the "Free nations of the World'. This was imbued with a geographical determinism that viewed geography as destiny: "Her independence is demanded by the Freedom of the Seas: her harbours are empty and idle solely because English policy is determined to retain Ireland as a barren bulwark for English aggrandisement." ${ }^{, 40}$

It was a reaffirmation of a bloody and failed coup d'etat that had taken place in April 1916. Beside this declaration there was an election of a 'cabinet' and a 'President'- Eamon d'Valera. A roll call was taken of the 73 names who had been elected largely unopposed in the British General Election of December 1918. A British Army report was specific as to why this situation had arisen: "Mainly as a result of intimidation, Sinn Fein secured the majority of seats, the representatives of other bodies being afraid to enter the lists." 41 The whole ceremony had an element of farce about it. Firstly, 36 of the 73 Sinn Fein MPs were serving custodial

\footnotetext{
${ }^{36}$ Irish Command produced a staff history titled :A Record of the Rebellion in Ireland in 19201921.This was a two volume work that covered both operations and intelligence. Hart has claimed that the volume on intelligence is by far the most trustworthy source there is on the two police forces, albeit one written from a military perspective.

37 This was an illegal declaration of independence that had no electoral mandate.

${ }^{38}$ The Times $21^{\text {st }}$ Jan 1921.

${ }^{39}$ Declaration of Independence, 21st January 1919,Documents on Irish Foreign Policy ,Vol 1 1919$1921 \mathrm{p} 1$.

${ }^{40}$ Ibid.p1

${ }^{41}$ General Remarks on the Rebellion in the $6^{\text {th }}$ Divisional Area, 1921 Strickland Papers IWM
} 
sentences. ${ }^{42}$ Secondly, three of the 'cabinet ministers': de Valera, Griffith , and Countess Markievicz, had been imprisoned for their role in an attempt to collaborate with the Imperial German Government during Operation Michael. ${ }^{43}$ Michael Rast has argued that its effect was not on the Britain, but on Irish nationalists themselves:'The British government did not see the Dáil as a serious enough threat to take active steps against it, but in republican minds a significant change took place on its establishment. Fighting for a government - though ridiculed and unrecognized legitimized the acts of aggression against Crown forces already taking place." 4

The nature of the UDI and the division of power in the republican movement can be gauged by the roles that were occupied by Michael Collins:"Being at the same time Minister of Finance responsible to the Dail, Director of Organization and, from June 1919, Director of Intelligence on the Executive of the Irish Volunteers, and finally President of the Supreme Council of the IRB, with notional leadership of the whole movement." 45 The geographical centre of gravity for this insurgency was Dublin and, to lesser extent, Cork. It was in the former city that that the various departments of the Dail were located and also the GHQ of the Irish Volunteers. These organisations functioned in backrooms, hidden offices, and were dependent on hidden files, and the movement of documents from one secret location to another.

One of the first murders took place on the day that UDI was declared in Dublin. As is often the case with volatile and extreme insurgent organisations these killings were not sanctioned by the leadership. In Soloheadbeg, just outside the town of Tipperary two members of the RIC who were escorting a civilian dynamite wagon to a quarry were shot dead by two members of the Irish Volunteers, Dan Breen and Sean Treacy: "The ambush contravened Volunteer GHQ's official policy, and Mulcahy (chief of staff of the Irish Volunteers) privately denounced it as an irresponsible attempt by extremists to bounce the army leadership into an

\footnotetext{
${ }^{42}$ C. Townshend, The British Campaign in Ireland 1919-1921,Oxford :Oxford University Press 1975.p14.

${ }^{43}$ As a consequence of Operation Michael, the German offensive on the Western Front in March 1918 the British Government felt it had no option but to introduce the Military Conscription Bill on the $9^{\text {th }}$ April 1918.Its application to Ireland was delayed. Three days later Joe Dowling ,a former British POW, and now a member of the German 'Irish Brigade "was arrested by the RIC as he landed from a German U-boat on the North Clare coast. His mission was to contact the leaders of Sinn Fein and promote the idea of another rebellion against the British authorities on the promise of a German expeditionary force being dispatched to Ireland.

${ }^{44}$ M. Rast, Tactics, Politics and Propaganda in the Irish War of Independence,1917-1921,MA Georgia State University ,2011 p48.

${ }^{45}$ Townshend ,op cit, p17.
} 
open war. He loathed the Tipperary leaders." ${ }^{\prime 4}$ This pattern of behaviour continued in February 1919, when the ' $3^{\text {rd }}$ Brigade' of the Irish Volunteers ordered all members of the British Army and the RIC to leave South Tipperary. Mulcahy refused to sanction the proclamation, but this element went ahead anyway and made the proclamation public. It was Collins who was instrumental in increasing the tempo of the insurgency throughout 1919. At the beginning of that year there was not a demand for an insurgency, even from the bulk of Irish Republicans. Perhaps more importantly, there was not a desire or widespread support by the population for an insurgency. Yet Collins's experience as a member of the secretive Irish Republican Brotherhood, prior to the 1916 Irish rebellion had taught him how a "minority within a minority" ${ }^{47}$ could successfully manipulate a larger organisation into violent action. Foy has succinctly described his approach:" His strategy was to first create a radical coalition - a war party- by winning over Volunteer GHQ and the Dublin Brigade, then create a war atmosphere by exploiting British Government mistakes and increasing popular frustration at political stagnation before bringing the crisis to a head through calculated acts of provocation." 48

By April 1919 he had forged an alliance with Dick McKee an IRB member and 'Director of Training' at the Irish Volunteers GHQ. Critically McKee made his limited resources available to Collins. McKee's access to Mulcahy also enabled him to cultivate the chief of staff. One of the lessons Collins had learnt from the 1916 Irish rebellion was witnessing how in the aftermath the detectives of ' $G$ ' Division of the Dublin Metropolitan Police were able to walk through a group of two thousand prisoners who were sitting on the floor of the gymnasium of Richmond barracks in Dublin and identify those prisoners who, from their intelligence, could be brought before a court martial under the Defence of the Realm Act. Collins was initially selected to join this group. ${ }^{49}$

Every revolution or insurgency needs an enemy, more specifically it designates part of the population in this role. ${ }^{50}$ When Collins took over from Eamon Duggan as Director of Intelligence in January 1919 he began this process. The first designated enemy was the part of $\mathrm{G}$ division of the Dublin Metropolitan Police that was responsible for the detection of

\footnotetext{
${ }^{46}$ M. Foy, Michael Collin's Intelligence War, Stroud :Sutton Publishing,2006 p17.

${ }^{47}$ This phrase was coined by F.X. Martin in his seminal article on the Irish rebellion ,'The 1916 Rising Coup d'Etat or Bloody Protest ,Studies Hibernica,8 1968.

${ }^{48}$ Foy, op cit p18.

${ }^{49}$ See T.P. Coogan, Michael Collins, New York:Palgrave, 1990 p45-46.

${ }^{50} \mathrm{I}$ am grateful to my colleague Dr Andreas Behnke for this insight.
} 
political crime in the city. The Irish Volunteers had already recruited three junior members of ' $G$ ' division, who were acting as inside agents ${ }^{51}$ for the Irish Volunteers. They were Eamon Broy, James Kavanagh, and Eugene Smith. Up until this period their ability to communicate actionable intelligence was limited. Collins initiated meetings with them on a personal basis, and then used Broy to gain access to two things that any intelligence organisation must keep secret: current sources and current methods. On $7^{\text {th }}$ April 1919, Collins entered 'G' Division's Brunswick Street headquarters. He was able to spend five hours having unrestricted access to all their intelligence records. Two days after this breach of security Collins was able to identify and coerce all the junior detectives responsible for political crime. The IRA threatened that they would be murdered unless they agreed to desist from undertaking any further intelligence gathering operations against the IRA. In addition, they were informed that they could continue to undertake investigations into ordinary crime..$^{52}$ There was still a hard core of experienced detectives who were not easily intimated. They were Detective Sergeants Holly, Hoey, Barton and Smyth. Broy considered Smyth to be the most experienced. Collins with Mulcahy's endorsement decided to murder them. Despite Rast's claim that the Dail legitimized the acts of aggression against Crown forces, Collins attack on' G' Division was: “ unauthorised by the Dail government and far ahead of mainstream republican thinking. It was something that he had to conceal from almost all his colleagues and superiors. ${ }^{.53}$

The period April to September 1919 saw an increase in the tempo of violence and intimidation. In April Sinn Fein designated the RIC as a target when it initiated a boycott of this national police force. This was not an easy thing for the IRA to undertake as Broy admitted : "The mere fact that these men were rather decent men in peaceful times made them all the more a menace when the national resurgence burst forth, and it took some time and some exhortation to convince local people that the RIC were really enemies." ${ }^{54}$ Very soon afterwards three policemen were murdered in Tipperary. The government's response was to proscribe Sinn Fein in that county only. The attacks on the RIC were motivated by a desire to eliminate its intelligence collection capability. Outside Dublin the RIC performed a unique intelligence function: "A particular menace to the Volunteers was the small area, policed by one sergeant and five

\footnotetext{
${ }^{51}$ This phrase comes from Sun Tzu's typology of human intelligence. See The Art of War chapter thirteen.

${ }_{52}^{52}$ Foy ,op cit p22.

${ }^{53}$ Op Cit Rast p25.

${ }^{54}$ Witness Statement by Eamon Broy No 1280 Bureau of Military Affairs ,Military Archives Cathal Brugha Barracks, Dublin, 1955.
} 
constables. The police in this case knew almost everything about every native of the area, and when a prominent Volunteer officer from Dublin came to the area, although previously unknown to the police in Dublin, was soon noted by the RIC as a stranger." ${ }^{55}$ These attacks and destruction of these small police stations were to cause serious gaps in intelligence capability. In the first three months of 1920; "Over 400 isolated police barracks were destroyed, and the Constabulary was concentrated, and immobilized, behind steel shutters in the larger buildings; and by May of that year some eighty members of the RIC and detectives in the Dublin Metropolitan Police had been murdered without any assassin being brought to justice. ${ }^{" 56}$ A British Army report written in 1921 noted the consequences of this action: "In 1919, they commenced their attacks on the RIC; they murdered them, they boycotted their families, they drove them from small isolated barracks. With what result? Police were recruited in England, and the British Army was drawn into the fray." 57

In Dublin two more of ' $G$ ' division's core of experienced detective sergeants were murdered between July and September on Collins's orders: Smyth and Hoey. The tipping point in terms of a government response came from an unexpected quarter, and was a reaction to yet another murder. This time a soldier from a small party of the King's Shropshire Light Infantry was killed as he was on the way to church in Fermoy, County Cork. It was the first fatality of a soldier since the rebellion of 1916. On $11^{\text {th }}$ September a letter from George V to the Prime Minister, Lloyd George demanded to know: "what the government was doing to do to protect the lives of suffering people in Ireland and what measures were to be brought into parliament for the government of the country. ${ }^{\circ 8}$ The next day it was announced that Dail Eireann was to be declared illegal. This meant that all the 'government departments' of Dail Eireaan and the Volunteer GHQ had to go underground. This necessitated moving to secret offices throughout Dublin and this was facilitated by Michael Noyk, a Jewish solicitor and Trinity College graduate ${ }^{59}$ Michael Collins calculated acts of provocation had been successful of bringing about the confrontation and insurgency he wanted. Furthermore, he was eroding the capacity of the police both in Dublin and in the rest of Ireland to provide intelligence on the IRA. David Galula has summed up the process that was underway: "an insurgency is usually slow to develop and

\footnotetext{
${ }^{55}$ Ibid.

${ }^{56}$ O. Winter, Winter's Tale, London: Richards Press, 1955 p291.

${ }^{57}$ General Remarks on the Rebellion in the $6^{\text {th }}$ Divisional Area, Strickland Papers, IMW P3(CHECK)

${ }^{58}$ Quoted in M.T. Foy, Michael Collins's Intelligence War, Stroud ;Sutton Publishing, 2006 p27.

${ }^{59}$ Ibid p35.
} 
is not an accident, for in an insurgency leaders appear and then the masses are made to move." 60

\section{ALFRED COPE AND COUNTER-INTELLIGENCE}

Alfred Cope's arrival in Dublin May 1920 was a fusion of two political failures on the part of the British state. The first was a decline in the legitimacy or social authority in the governance of Ireland as an integral part of the United Kingdom. This was not a new phenomenon. It had been highlighted by the Royal Commission on the Irish rebellion which had published its findings in May 1916: "The main cause of the rebellion appears to be the lawlessness was allowed to grow up unchecked, and that Ireland for several years past has been administered on the principle that it was safer and more expedient to leave the law in abeyance if collision with any faction of the Irish people could thereby be avoided. Such a policy is the negation of the cardinal rule of Government which demands that enforcement of law and preservation of order should always be independent of political expediency." 61 These findings also exposed a pivotal weakness of the Royal Commission process. It had legally binding investigative powers, but it lacked any mechanisms of enforcement whereby the Asquith Government or any subsequent governments could be compelled to remedy these failings.

An insight of how far the legitimacy of government had been allowed to become subordinate to political preferences was given by Augustine Birrell, the Chief Secretary for Ireland from 1906 to his sacking in 1916: "I had seen my own policy clearly from the first. It was to pave the way for Home Rule (on more or less Gladstonian lines), and to do all that in me lay to make any other solution of the problem impossible". ${ }^{62}$

General Macready, although not in Ireland during the rebellion, identified a direct link between the rebellion and the insurgency that gathered pace after 1919 and the responsibility of British policy makers for their handling of the aftermath of $1916 .^{63}$ This was compounded by a malaise that Colonel Foulkes ${ }^{64}$ discerned: "By the end of the First World War they (the police) had not been in a position to enforce the law. For

\footnotetext{
${ }^{60}$ D.Galula,Counter-Insurgency Warfare Theory and Practice, Westport :Praeger 1964 p12.

${ }^{61}$ The Royal Commission on the Rebellion in Ireland ,CD 8279 HMSO, London ,1916 p12.

${ }^{62}$ A Birrell (1916 article

${ }^{63}$ Macready cited the 'policy of compromise' pursued by Asquith for changing the atmosphere of contempt for the rebels into one of patriotic glory and for sowing the seeds of subsequent assassination ,rebellion and internecine strife .See N. Macready, Annals of an Active Life Vol 2 , London: Hutchinson, 1924 p242.

${ }^{64}$ Colonel Foulkes RE was a regular army officer who served in Ireland between 1919 and 1921 From May 1921 he served as a Director of Propaganda at Army GHQ in Dublin.
} 
example stop poaching, cars been driven at night without lights, cattle on the road grazing, bicycles on the footpath. They had lost their prestige. By the end of 1919 the two police forces were far from being an effective force. They then found themselves in small detachments and isolated; boycotted by Sinn Fein threatened, abused and murdered." ${ }^{65}$

The second reason for Cope's appointment was the posting of a new GOC for Ireland. In March 1920, General Shaw had been replaced by General Macready, a personal choice of the Prime Minister Lloyd George. ${ }^{66}$ Since his arrival in Dublin he had sent a series of reports stating that, "administrative chaos seems to reign here, where the machine was hopelessly out of gear." ${ }^{97}$ The government's response was to ask Sir Warren Fisher, the Head of the Civil Service, to examine the functioning of Dublin Castle, the centre of British administration. Fisher arrived on $4^{\text {th }}$ May with a two man team. R.E. Harwood from the Treasury, and Alfred Cope then still working in the Ministry of Pensions. The main focus was the workings of the office of the Chief Secretary. The report was completed on 12th May. Out of this report came a series of new appointments of which Cope's was to be but one. The new Under Secretary was Sir John Anderson, then Chairman of the Board of Inland Revenue. Cope was appointed Assistant Under Secretary along with Mark Sturgis from the Treasury. ${ }^{68}$ Anderson and his team arrived in Dublin on $22^{\text {nd }}$ of May 1921.An insightful portrait of Cope and his political preferences was given by Macready who was to interact with him constantly in the next two years: "a tireless worker, highly strung, a firm believer in self -government for Ireland... and feverishly anxious to do all in his power, even at the risk of his life, to ensure the success of $\mathrm{Mr}$ Lloyd George's policy, his somewhat irritable shortness of manner and an insufficiency of official oil when the waters became troubled made him decidedly unpopular with many of those with whom he came in contact. .69

\footnotetext{
${ }^{65}$ Foulkes Papers 7/4,Liddell Hart Military Archives ,King's College London.

${ }^{66}$ Macready was favoured over other candidates for the post because he was liked by Lloyd George and was deemed to have a right experience. He: 'had made his mark as Adjutant General in the last two years of the war, and as Commissioner of the London Metropolitan Police, where had had dealt with the police strike of 1919. His career had embraced the command of troops in South Wales at the time of Tonypandy , as well as in Belfast during the crisis of 1914" C Townshend, The British Campaign in Ireland 1919-1921,Oxford:Oxford University Press ,1975 p74.

${ }^{67}$ Quoted in E. O'Halpin, Head of the Civil Service ,A Study of Sir Warren Fisher, London: Routledge, 1989,p85.

${ }^{68}$ Sturgis was not gazetted for two years for fear of wounding Cope's sensibilities. See C Townshend, The British Campaign in Ireland, 1919-1921.Oxford: Oxford University Press 1975p80.

${ }^{69}$ N. Macready, Annals of an Active Life, London: Hutchinson \& Co Vol 2 p492-493.
} 
Bew has claimed that this set of appointments signalled a pivotal shift in the political preferences of the administration in Dublin Castle. "A new clique was created which governed policy. A network was instituted involving 'flexible' Irish officials like W.E. Wylie, the crown prosecutor and G.C. Duggan of Dublin Castle; above all, new English officials like Sir John Anderson and Andy Cope, now the driving force in Dublin Castle. This group worked closely with Philip Kerr in the prime minister's office. Sir Basil Thomson, at Scotland Yard and C.J. Philips ,chief assistant to the foreign secretary, Lord Curzon." ${ }^{, 70}$ Four years after the findings of the Royal Commission there was now installed in Dublin Castle, yet another group of civil servants, who would ensure that again the enforcement of law and preservation of order would be subordinated to political expediency: the antithesis of 'the cardinal rule of Government'. Bew has challenged the accepted judgements of Irish historians who have characterised British policy as one of incoherence. ${ }^{71} \mathrm{He}$ has argued that this new group had a confidence to worship at the altar of treating with the insurgents and bring Lloyd George to it as well: "this group had a clear picture of the settlement from the outset and a confidence in their ability to deliver, in the end, the prime minister." 72 This latter claim pivots on some understanding of Lloyd George's existing views on the governance of Ireland. Prior to this period there is evidence to suggest that he was a firm believer in what could be described as a limited devolution: "Lloyd George had from his earliest days as a Welsh nationalist maintained one consistent principle of Irish policy -that Home Rule would not mean separation. He believed like Joseph Chamberlain in the strategic and fiscal unity of the United Kingdom. The war and the deep concern it brought with it about the strategic safety of the British Isles only strengthened his resolve on that point.". ${ }^{.3}$

When General Macready arrived in April 1920 he assessed that the effectiveness of ' $G$ ' Division had been blunted by what he described as 'systematic murder', and the RIC was in a state of 'disintegration. ${ }^{.74}$ In terms of destroying the effectiveness of police intelligence gathering capabilities Michael Collins made an assumption that the murder of these detectives and policemen would bring about a deficit of intelligence that

\footnotetext{
${ }^{70}$ P. Bew, Moderate nationalism and the Irish Revolution „,The Historical Review ,Vol 42,No 3 , (Sept ,1999) p743.

${ }^{71}$ Ibid p743.

${ }^{72}$ Ibid p743.

${ }^{73}$ D.W.Savage, "The Parnell of Wales Has Become the Chamberlain of England "Lloyd George and the Irish Question. Journal of British Studies, Vol 12 No 1 (November 1972) p106.

${ }^{74}$ Macready ,op cit, p435.
} 
could never be filled: "even when the new spy stepped into the shoes of the old one, he could not step into the old one's knowledge."75

What is remarkable about this period from May 1920 to July 1921- just over 14 months - is how wrong Collins was. In reality the British were able to build up and expand an effective intelligence organisation very quickly.

An example of what the Army's sub rosa intelligence organisation had been able to achieve is illustrated by a secret memo, dated the $6^{\text {th }}$ August 1920, from General Macready to Sir John Anderson, the new Under Secretary. It contains clear evidence that the army had managed to capture policy documents that came from the top of the Republican movement : "Brind (a staff officer at GHQ) sent to the Castle yesterday copies of some most important correspondence that we have got hold of, laying down the policy that is being carried out by our ${ }^{76}$ Arthur Griffiths in regard to the establishment of the Republican Government."77

An intelligence organisation that had been set up in June 1920 was called the Special Branch Dublin District, and commanded by Lt Col Walter Wilson: "Wilson divided the Dublin district into six areas under head agents whose cells of Special Branch officers and civilian informers collected information on IRA personnel, Volunteer arms dumps ,operations, safe houses, and potential targets as well as reporting on the state of enemy morale. They also tried locating the Dail, Volunteer GHQ and the Dublin Brigade offices and leading republicans like Collins and Mulcahy." ${ }^{78}$ It was set up as a response to the increasing tempo of the insurgency and to compensate for the intelligence vacuum that was left by the ineffectiveness of ' $G$ 'Division of the DMP: "In the early summer of 1920 intelligence primacy still lay with the army, and, as a result of increasing IRA attacks on soldiers ,many officers volunteered for intelligence duty. Dublin Military District's intelligence branch was reorganised and a plain clothes section known as Special Branch Dublin District created to collect military and political information in the capital." ${ }^{79}$ The hallmark of its success can be judged by two criteria: material captured and arrests made. More importantly, its officers were to carry out the first, albeit inadvertent, counter-intelligence operation that was to locate and identify Cope's relationship with Sinn Fein and produce

\footnotetext{
${ }^{75}$ Rast ,op cit $\mathrm{p} 58$.

${ }^{76}$ The use of this possessive pronoun may provide an unexpected perspective into his political loyalties.

${ }^{77}$ Secret Memo from General Macready to Sir John Anderson ,6 August 1920, Sir John Anderson's Papers, National Archives CO 904/188.

78 M. Foy, Michael Collin's Intelligence War, Stroud : Sutton Publishing .2006 p105.

${ }^{79}$ Foy ,Op Cit,p103.
} 
prima facia evidence of his willingness to leak confidential information to the insurgents. Another important point that needs to be made is that his activities were unmasked largely because of the paradox that lies at the heart of counter -intelligence: "Although the purpose of counterespionage is defensive, its methods are essentially offensive". ${ }^{80}$

Captain Robert Jeune was a member of Special Branch Dublin District. His testimony conveyed the offensive methods used by the army in Dublin to counter the intelligence deficit they faced in the first half of 1920 : "A rather hastily improvised intelligence organisation was formed ,of which I was a member, and after a short course of instruction at Hounslow, we were sent over to Dublin in the early summer of 1920."81 The aim of this new unit was both to put in place both a process and an end product: "the work consisted of getting to know the town thoroughly, tailing the 'Shinners', and carrying out the small raids, with a view to collecting all possible information which lead us eventually to stamping out the revolt." ${ }^{\prime 82}$ It was through the use of this tactic that Cope's activities first came to light: "In September 1920, a raid took place which had a significant result. It was decided to raid several houses in the Drumcondra area. Particular attention was paid to the house of a man called O'Connor, known to us as an active Sinn Feiner... There was no hostile reception, however, and the search went on. While this was happening I was standing talking to Boddington, who was in charge of the raid, when a letter was brought to him which he read and handed to me saying:

'Money for Jam'. It was on official Dublin Castle paper and was in these words:

Dear Mr O'Connor,

I am having the papers you require sent up to you.

Yours sincerely

A.W. Cope

This was distinctly interesting. Here was the Assistant Under Secretary writing to a notorious Sinn Feiner, with whom he had obviously already been in contact. After this I made a point of trying to find out more about this individual's doings, and found that he had done some rather strange things, such as arranging for some electricians of known Sinn Fein views to come into the Castle at unusual times. ${ }^{83}$ Also he was one of the very

\footnotetext{
${ }^{80}$ Dulles Op Cit p124.

${ }^{81}$ Papers of Captain Robert Jeune 76/172/1 IWM

${ }^{82}$ Ibid.

${ }^{83}$ This facilitating the access by Cope of Sinn Fein activists to Dublin Castle can be interpreted as an act of treason.
} 
few castle officials who could safely walk about the streets of Dublin. But it was decided that no drastic action could be taken against him ,as it turned out he was a protégé of Lloyd George, who picked him out of Fisheries(it was Pensions)and sent him over to Ireland under Sir John Anderson in order to get a foot in the Sinn Fein Camp." ${ }^{84}$

Within four months of his appointment, Cope was passing information much of it secret to Sinn Fein, and giving its members unauthorised access to Dublin Castle. His ability to do this was a direct consequence of the role that he had carved out for himself. Sturgis's diary for $22^{\text {nd }}$ September 1920 revealed the institutional channel he used: "He (Cope) has now taken over RIC transport and correspondence branch en bloc! I'm not sure he has not done his reorganisation Castle job ( as nobody else could). ${ }^{" 85}$ Cope was to inject a highly damaging disconnect into the governance of this part of the United Kingdom. The smooth and sustained functioning of a key relationship was undermined: "the relationship between strategy and its enabling tactics requires, as a matter of absolute need, that policy needs, which is to say political choices, provide both legitimacy and practical guidance" ${ }^{86}$ Cope was to provide neither.

In May 1920 the British government considered that the intelligence deficit that both police forces faced required further augmentation. To this end they appointed Brigadier-General Ormonde Winter as Deputy Chief of Police. This title was a cover for his real role which was Chief of the Combined Intelligence Services. Sturgis described him in the following way:" ' $\mathrm{O}$ ' is a marvel-he looks like a wicked little white snake and can do everything! He is an Artillery Colonel and commanded a Division of artillery in France; in India, they say, he was tried for murder for a little escapade when doing secret service work. He started a race course near Calcutta and made a pot o' money... When a soldier who knew him in India heard he was coming to Ireland he said 'God Help Sinn Fein, they don't know what they are up against." ${ }^{\text {"7 }}$ Winter also had to liaise with Scotland Yard, the Director of Naval Intelligence, the Military Intelligence Officers and the Crime Special Department of the RIC.

Winter made quick progress in gaining highly personalised information on the movements of Michael Collins. By $3^{\text {rd }}$ September 1920 , only four

\footnotetext{
${ }^{84}$ Ibid.

${ }^{85}$ Sturgis Diary, op cit, p43.

${ }^{86}$ C.S Gray, Tactical Operations for Strategic Effect :The Challenge of Currency Conversion,JSOU Report ,November 2015,p14.

${ }^{87}$ The Last Days of Dublin Castle, The Diaries of Mark Sturgis,(ed M. Hopkinson) Dublin: Irish Academic Press 1999, p32.
} 
months after his arrival in Ireland, Sturgis revealed the extent of the inroads he had made : " $O \mathrm{O}$ ' is on the track of Michael (Collins)-he was amusing about a report he wanted to send to the Under Secretary (Sir John Anderson) but couldn't as it would have said that Michael slept with a girl, address known, once a week , and this he shrank from dictating to his chaste female shorthand writer. So he had to give his news by word of mouth." ${ }^{" 18}$ What is curious is that no evidence can be found of this intelligence being actioned by Anderson.

As Chief of Combined Intelligence Services Winter's most important innovation was the setting up of two new intelligence organisations: the Central Office of Intelligence and the Central Raid Bureau and a number of supporting yet related organisations. The first one covered the whole of Ireland in terms of its geographical scope, and was divided into a number of sub organisations. In a report that Winter wrote titled: The 'Intelligence Branch of the Chief of Police ${ }^{89}$ he gave an insight to the structures and how they worked:"A Central Office was formed, through which all information should pass, be tabulated ${ }^{90}$ and disseminated. Outside Police Centres were linked up to the Central Office by the formation of Local Intelligence Centres, which were responsible for collecting and passing on information between the Army and the Police, and formed the necessary branches of the main trunk. For convenience of control, these were situated at the Headquarters of Divisional Commissioners of the RIC. Police information was augmented, as far as possible, by the employment of chosen agents, and a Bureau was established in London, under special cover, to deal with all sources of information other than those obtained through ordinary channels ,to collect information and pass it to the Central Bureau." ${ }^{\text {"W1 }}$ What is worth emphasizing is the relative speed with which this structure was set up - in just six months .The first Local Intelligence Centre was functioning in Belfast by January 1921.Between March and April LICs were operational in Limerick, Kildare, Athlone, Galway, and Dundalk. The last one was in Clonmel was functioning by July 1921. Winter acknowledged that the greatest challenge was recruitment: "The difficulty of obtaining and training suitable personnel somewhat retarded the formation of Local Centres , and the last one to be formed was only established at Clonmel a week before the Truce. ${ }^{.92} \mathrm{He}$ was aware also of the security challenge

\footnotetext{
${ }^{88}$ Ibid p35.

${ }^{89}$ It covered the period from May 1920 to July 1921

${ }^{90} \mathrm{~A}$ more modern understanding of this process would be the recording, collating, analysing and assessing information for necessary action.

${ }^{91}$ A Report on the Intelligence Branch of the Chief of Police from May 1920 to July 1921.CO 904/156b, National Archives, Kew.

${ }^{92}$ Ibid
} 
faced with respect to recruitment: "The selection of suitable members for the Central Intelligence Bureau presented many serious obstacles. As a precautionary measure the personnel for the clerical services were all selected from individuals of English extraction, whose antecedents and activities were carefully screened by Scotland Yard. Nearly all the stenographers employed were women, and the male staff were all exofficers of the Army or Navy." 93

The second institution was the Central Raid Bureau, which was functioning by October 1920.This had an important role in that it enabled Courts Martial officers to gather evidence that could be used to prosecute members of the IRA. A point that has often overlooked in the existing literature. ${ }^{94}$ More importantly, Winter understood the importance of organised searches in terms of providing accurate and timely intelligence: "The word of an informer is, very frequently, unreliable, but the evidence deduced from a captured document is tangible, and can generally be regarded as conclusive. It was mainly documentary evidence that enabled the authorities to obtain and hold, in the face of appeals, the vast number of internees , and led to the successful prosecution of many agitators. Endeavours were made to inculcate into all concerned the value of forwarding to the Central Bureau all documents captured in raids." 95

There was also an understanding of the need to subject raw intelligence to a process of analysis and the implications that it could have for fighting the insurgency: "Letters seized in one part of Ireland were often meaningless, but, when compared with documents, in a similar handwriting, captured in another locality, either afforded valuable clues or led to the prosecution of the writer." " . Collation' as Winter described it led to arrests of what he described as 'political criminals' and their subsequent internment or imprisonment. This resulted in an intelligence boost as the threat of interment would illicit more intelligence from suspects. Information was obtained that led the framing of charges or providing direction for further action. This in turn brought about more organisational innovation: "A Legal Branch, with a staff of interrogators, was formed, which put up cases for interment or prosecution. This dealt with cases in Dublin District, whilst the Officers in charge of the Local Centres functioned in a similar way in respect to the country, as soon as the Local Centres were established". ${ }^{97}$ The effectiveness can be gauged

\footnotetext{
${ }^{93}$ Winter, op cit $\mathrm{p} 302-303$.

${ }^{94}$ See for example PT. Coogan, Michael Collins, New York: Palgrave 2002 p143-147.

${ }^{95}$ Winter Op Cit p16.

${ }^{96}$ Ibid p16

${ }^{97}$ Ibid p17.
} 
from the fact that in the Dublin District alone from $21^{\text {st }}$ November 1920, to $21^{\text {st }}$ February, 1921 , a period of three months , 1745 arrests were effected. Furthermore, from December 1920 to June 1921, 310 revolvers ,34 rifles ,20 shot guns ,many thousands of rounds of ammunition, and a large quantity of bombs ,explosives and detonators were recovered. ${ }^{98}$

These intelligence organisations were highly dependent on one source of intelligence above all else: the capture of documents. This would primarily be achieved through organised searches. This was recognised by the GOC in Ireland, General Macready: "It must be remembered also that most of our Intelligence comes from raids or from the result of captures made when actively engaged with the rebels. Some of my people put the proportion of Intelligence so obtained as high as eighty per cent of the total information received." 99 The Raid Bureau was staffed by clerical staff who had been vetted by Scotland Yard. In terms of processing the captured documents Winter set up a two part process. The first was the recording, collating, analysing and assessing for necessary action all the documents that had been seized. The second was the production and distribution of what were called epitomes ${ }^{100}$. These could then be accessed by the police and army who could use them to undertake further action.

These epitomes provided the basis of actionable intelligence. They provided a summary of recently captured documents, or a quote from one that was judged to be of particular pertinence. They could act as a trigger mechanism whereby a military or police unit could call for the original document if they thought they would act as a basis for further action. Winter gives a sense of both the scale and the success of this organisation: "Some idea of the amount of work involved may be gathered from the fact that in the Dublin District area from October 1920 to July 1921, 6,311 raids and searches were carried out, and over 1200 epitomes of captured documents, some consisting of over 200 pages of foolscap were circulated." 101

In an assessment of the IRA's intelligence capabilities, written by the British Army in 1922 these organised searches were judged to be one of three reasons why the accepted judgement of eulogising the IRA's use of intelligence needs to be understood in a more sober light: "With almost every advantage Sinn Fein intelligence was not as good as it might have

\footnotetext{
${ }^{98}$ Ibid p17-18

${ }^{99}$ General Macready to Chief Secretary(Green wood) $27^{\text {th }}$ April 1921,Lloyd George Papers, F/19/4/7 House of Lords Library.

100 These were short summaries or abridgements of the captured documents.

101 Winter ,op cit p304.
} 
been. This was mainly due to their ignorance of the principles of organisation. It was also due to constant raiding and searching by the Crown Forces, which made it impossible to establish an office where records and files could be kept in safety and to the fact that most subordinate officers and the rank and file were apathetic about the service of information." $" 102$.

Another weakness was a consequence of the relative lack of technology accessible during this period. The IRA could not avoid committing information to paper in the absence of any other medium or technology of communication. Verbal communication except for messages containing no more than a few words were always liable to corruption in terms of understanding. Written documents were the main medium of communication and as Winter understood they were always vulnerable to capture. In addition, he believed that there were ethnic proclivities at play which advantaged the security forces: "It was fortunate that the Irish had an irresistible habit of keeping records. They would hide them in the most unexpected places, but they seldom evaded discovery by the trained sleuth; and by this time the Dublin District Service men became outstanding experts." 103

\section{ALFRED COPE AND THE LEADERS OF THE INSURGENCY: THE SECRETS OF COUNTER-INTELLIGENCE.}

Two salient points can be made with respect to the intelligence organisations that Winter set up. First they provided a unique perspective on counter-intelligence. It underlined the importance of what has previously been called 'counter-intelligence information'. ${ }^{104}$ This was a process of gathering, recording, collating, analyzing, and using CI information to support operations to counter the insurgency. It was a result of this process the Central Raid Bureau could follow Cope's developing relationship with Sinn Fein. There were now in place intelligence organisations that could provide what Kent had termed surveillance and research operations.

Secondly, this framework enables the dominant teleological narrative of British incompetence and mendacity as far as intelligence operations were concerned to be challenged. Evidence of both types of counterintelligence operations can be gauged by Sturgis's diary entry for $16^{\text {th }}$

\footnotetext{
${ }^{102}$ A Record of the Rebellion In Ireland in 1920 -1921,and the Part Played by the Army in Dealing with It Vol 2,Intellignece in Ireland 1920-1921 p46.

${ }^{103}$ Winter, op cit p303-304.

${ }^{104}$ See $\mathrm{p} 2$
} 
November 1920:"A raid last night $\left(15^{\text {th }}\right.$ November $)$ on the house of the IRA 'Chief of Staff' called Mulcahy has been productive of some amazing stuff .The gent himself succeeded in getting away in his nightshirt, which is a pity but the papers seized give evidence of the most thorough and complete plots to murder individuals, poison troops, horses etc.-to blow up the Manchester Ship Canal ,etc, etc." ${ }^{105}$ There was also evidence recovered that led to IRA bank accountants: "Wilson (Head of the Special Branch Dublin Military District) came in hot after Mulcahy's money -he also it seems has an account or accounts in the Bank at our gates in different names. Wilson and Wynne had their heads together for an hour and I hope settled satisfactorily the least illegal way of bagging the stuff." ${ }^{106}$.This intelligence demonstrated that in a relatively short period, operational level IRA networks, such as their bank accountants, were being uncovered and subverted. Furthermore, there was an understanding of the need to exploit these captured documents as quickly as possible this establishing a tempo of operations. Three days after the raid on Mulcahy's house, on $19^{\text {th }}$ November, follow up organised searches were launched with a specific agenda:"Among the Mulcahy's papers is a list of 200 gun men, names and addresses and classified as very good shots, good shots etc. We are out raiding tonight for these beauties and will have them on the run anyway if they've taken fright and bolted." 107

Six days after this raid, the IRA responded. On Sunday $21^{\text {st }}$ November 1920, 12 intelligence and courts martial officers were murdered, and another five were wounded, some in front of their wives, in a series of coordinated attacks on civilian addresses and one hotel in the centre of Dublin. There is an extensive literature on this event and it is not intended to restate the narrative of these events. ${ }^{108}$ These killings are often interpreted as a turning point in the whole campaign. ${ }^{109}$ Hart has challenged this interpretation: "The information it was based on was imperfect and some of those shot had nothing to do with spying or trails." 110 This raises the question why Collins launched these attacks? There are two answers: first in a veryshort period of time British intelligence operations had put pressure on the leaders of the insurgency and their organisation. Captain Robert Jeune provided the best insight to

\footnotetext{
105 Sturgis Diary ,op cit p73.

106 Sturgis Diary ,op cit p74.

107 Sturgis Dairy ,op cit p76.

${ }^{108}$ For example see M. Foy Michael Collin's Intelligence War ,Stroud: Sutton Publishing ,2006 p141-

177. Also T.P. Coogan ,Michael Collins,

${ }^{109}$ Evidence here

${ }^{110}$ P. Hart, British Intelligence in Ireland 1920 -1921,The Final Reports, Cork: Cork University Press,2002 p12.
} 
this. He had received unspecified warnings concerning the attacks that took place on the $21^{\text {st }}$ November: "In November, (1920) information was coming in well and we were beginning to get on top of the IRA, who were becoming desperate. I happened to receive information from three different sources to the effect that something was going to happen, but there was nothing definite." 111 .The intelligence officers who were killed had set up and were running networks of Irishmen to provide information on the IRA. This is attested to by James Cahill one of the IRA gunmen: "Our intelligence had located the chief British intelligence officers who were living in various hotels throughout the city. (this is not true, as the bulk were in private lodgings.) Each officer had a number of spies or touts who kept him supplied with information. It was planned to shoot all of those intelligence officers the next morning." 112

Important changes in the legal system had taken place since August 1920.In that month the British government enacted the Restoration of Order in Ireland Act .This act replaced the civil judiciary with a courts martial system. These courts were empowered to try people for treason, treasonable felony and felony. More importantly Courts Martial officers began building cases against members of the IRA and prominent Republicans. It was the confluence of access to accurate intelligence and the work of the Courts Martial officers that was squeezing the IRA: "The object of this exercise(the murders of the $21^{\text {st }}$ November) on the part of the IRA, was to eliminate Intelligence and Courts Martial officers ,because the gunmen felt that the net was closing round them. So men were brought up to Dublin from other parts of the country, particularly Tipperary, in order to catch as many as possible of us unawares on a Sunday morning, when most people slept late."113

There is no doubt that these killings caused a halt in the intelligence activities of the Special Branch, Dublin Military District.: "As a result of all this, those of us who had survived were shut up under guard in a hotel ,from where it was impractical to do any work. In fact our job had to all intents and purposes been done, and the organisation was breaking up." 114

Hart has argued that Collin's achievements were more modest and did not go beyond the tactical:"His sources rarely gave him useful operational intelligence other than warning of some raids and spies. He did not

\footnotetext{
${ }^{111}$ Papers of Captain Robert Jeune 76/172/1 IWM.

112 Commandant James Cahill, Witness Statement No 503, Bureau of Military History ,Military

Archives Cathal Brugha Barracks, Dublin .

113 Jeune Papers ,op cit

114 Jeune Papers op cit
} 
acquire any particular insight into British planning or intentions." 115 Furthermore, he has argued that 'Bloody Sunday' was not the 'Napoleonic masterstroke' of Irish Republican legend: "Rather than bringing relief, the shootings actually precipitated the worst setback yet for the rebels at the hands of British intelligence. Military and police intelligence officers had by now identified most of their opponents. Raiding parties were unleashed all over Ireland to round up known IRA officers and activists and detention camps were hurriedly established to receive the large numbers of men caught in the net. Informers sprang up once again and arms were found in unprecedented numbers." 116 Hart's judgement is confirmed by a conversation that took place in January 1921. Captain Jeune met General Boyd, GOC Dublin District, on the boat train to Holyhead. They both concurred that another six months would see the IRA unable to sustain the insurgency. ${ }^{117}$ Jeune also provides a reference, albeit an oblique one, to the forces that were to derail the progress that British intelligence and the security forces had made against the IRA: " by the early summer (1921) the IRA, were driven into the south west corner of Ireland, and would have been quickly finished. But certain influences were to save them."118

What these 'certain influences' were can be found in the epitomes that were compiled by the Central Raid Bureau. They provided a counterintelligence on a senior British civil servant and demonstrated he was in contact with the leaders of the insurgency. It is clear that he did not make the headway he would have liked. In a raid that took place on $16^{\text {th }}$ December 1920,the raid epitome stated: "21(6) Slighting reference to Cope by J.E. Duggan to Michael Collins." 119 This lack of trust needs to be understood in the context of the challenges that Collin's own intelligence network was having to respond to. By the end of 1920 the detection of political crime had been transferred from the DMP to Dublin Castle. In addition, sustaining the low grade sources inside G Division had become problematic. One of his sources, Kavanagh had died after an appendix operation. During a raid by the Auxiliary Division of the RIC on New Year's Eve 1920 on a flat in Dawson Street, documents were found that linked Broy to the IRA. ${ }^{120}$ They included:"Broy's copies of G Division reports which were well over a year old and should have been

\footnotetext{
${ }^{115}$ Hart op cit $\mathrm{p} 11$.

${ }^{116}$ P. Hart (ed) ,British Intelligence in Ireland: The Final Reports 1920-1921,Cork : Cork University Press, 2002 p12.

${ }^{117}$ Ibid

118 Ibid

${ }^{119}$ Epitome of Documents seized at 5 Mespil Rd No 53/4435, $16^{\text {th }}$ December 1920.Foulkes Papers Basil Liddell Hart Archives.

${ }^{120}$ Broy was finally arrested on $17^{\text {th }}$ February 1921 detained in Arbour Hill prison in Dublin and charged with high treason in April 1921.
} 
destroyed." 121 More importantly the Auxiliaries had discovered an important IRA hub. The flat was the home of Eileen McGrane, who acted as a private secretary to Collins. She was storing a mass of intelligence documents in her flat. The importance of this raid can be gauged from the fact that it was one of the few covered in detail in Winter's autobiography: "accompanying her(to Dublin Castle) was a van load of captured documents ,together with three automatics and a quantity of ammunition.The fact that the epitome of these documents occupied 356 pages of closely typed foolscap, was indicative of the number of her activities, whilst the nature of the contents added considerably to our volume of intelligence." 122

A key challenge that Cope faced was one of establishing trust. This was compounded by a modus operandi that attempted to ensure that Sinn Fein would put forward political demands that would enable the British government to respond in a manner that would deflect any accusation that they were acceding to Sinn Fein's demand of a fully independent Irish Republic. An early British position was that there could be no truce unless arms were surrendered. One of the few insights to these exchanges was given by Frank Gallagher. ${ }^{123} \mathrm{He}$ cited a communication written by Collins on $14^{\text {th }}$ December 1920 to Arthur Griffith and a number of Republican prisoners ${ }^{124: ~ " W e ~ h a v e ~ c l e a r l y ~ d e m o n s t r a t e d ~ o u r ~ w i l l i n g n e s s ~}$ to have peace on honourable terms .Lloyd George insists on capitulation. Between these there is no mean." 125

Cope continued to search for channels that he could both use and manipulate:" Irishmen in the Crown service were used as contacts by Cope in his secret efforts to bring about peace. Cope was in his element in these undercover activities but lacked the stability and perception to bring them to a successful conclusion." ${ }^{126} \mathrm{He}$ also attempted to impute onto Sinn Fein what were in reality British negotiating positions. In January 1921, Father O'Flanagan, the Vice President of Sinn Fein was an example of this :"Cope said that Father O'Flanagan would propose a settlement to Lloyd George on the lines of Dominion Home Rule". ${ }^{127}$ These 'peace plots' as Sturgis referred to them continued in the midst of the insurgency. Nine days after the raid on McGrane's flat, and the operational triumph that this represented, the British government

\footnotetext{
${ }^{121}$ M. Foy, Michael Collin's Intelligence War, Stroud: Sutton Publishing, 2006 p189.

122 Op Cit Winter p328-329.

${ }^{123}$ Frank Gallagher was head of the Republican

${ }^{124}$ They were Michael Staines, Eamonn Duggan, Eoin MacNeill.

${ }^{125}$ Cited in F. Gallagher, The Anglo -Irish Treaty, London :Hutchinson.1965 p23.

${ }^{126}$ Ibid p27

${ }^{127}$ Ibid p25.
} 
embarked, in secret, on negotiations that drove a wedge between policy and strategy and the activities of the police and army. Although, as Strachan has argued, strategy and policy are distinct in theory, in practice strategy rests on a dialogue with policy. ${ }^{128}$ Cope's activities underlined a clear abandonment of strategic logic. It is the same for regular and irregular wars, the deployment and use of armed force to develop an effect sufficient to modify the enemy's will. Cope's objective was the antithesis of this. A demonstration of this was given on $9^{\text {th }}$ January 1921 , the Prime Minister Lloyd George ,Cope and Sturgis were involved in a: "very secret interview was arranged for that morning between the PM, O'Connor and Father O'Flanaghan and that the two Irishmen would have a preliminary rendezvous in the Treasury with Andy and myself and that probably the Chief Secretary would come in. As we talked Andy was saluted by an insignificant looking little man with a black moustache and a tall well set young looking priest-Lord Justice O'Connor, Master of the Rolls and Father O'Flanaghan, Acting Vice President of the Irish Republic."129

The communications between Irish Republicans that preceded this meeting revealed both insecurity and fear of being manipulated by the British. In a letter to Art O'Brien ${ }^{130}$ dated $5^{\text {th }}$ January Collins revealed his suspicions: "To be plain about it Cope is lying. He must know that the Castle authorities made the approach to Fr O'F."131 In secret and at the highest level the government was willing to negotiate in the midst of a violent insurgency. Sturgis revealed the outcome of this meeting in his diary: "Father O'Flanagan is ready to stump Ireland against the Republic, in favour of working the Home Rule Act plus "fiscal autonomy." 132

The 'Castle group' of civil servants from January to July 1921, the date of the truce, had brought about a dangerous disconnect in the governance of this part of the United Kingdom. Sturgis articulated clearly the length they were prepared to go: "there is the feeling that many of them (Sinn Fein) are murders with whom we cannot treat.....Still I can't deviate in my opinion that give these people a little now and they are to that extent men bribed, and men bribed are always a bit under one's thumb."133 If there was one decision that encapsulated this tendency, it was the extension of de facto legal immunity to de Valera. Macready has claimed that as soon as he arrived back in Ireland from the United States, in the

\footnotetext{
${ }^{128}$ H. Strachan, The Direction of War, Cambridge: Cambridge University Press,2013 p19.

${ }^{129}$ Sturgis Op Cit p107.

${ }^{130}$ Art O'Brien was the (to be finished)

${ }^{131}$ Quoted in F. Gallagher, The Anglo-Irish Treaty, London: Hutchinson, 1965 p25.

${ }^{132}$ Sturgis Op cit p108.

${ }^{133}$ Ibid p112.
} 
first week of January 1921, he received instructions from Dublin Castle that he was not to be interfered with or arrested ${ }^{134}$

However, he was wrong about the institutional source of this immunity. Sir John Anderson, the Under Secretary in Dublin Castle gave a more accurate indication to the Irish Situation Committee:"The fact that de Valera had been in or near Dublin for many months, the Irish Authorities had continually received information regarding meetings which De Valera attended personally in company of other rebels who were badly wanted. It had been impossible to raid these meetings in view of the Cabinet instructions.... These restrictions had a hampering effect far beyond the immediate inhibitions imposed." "135 Anderson's statement underscored the accuracy of the intelligence the Irish authorities were receiving and the corrosive effect on counter- insurgency measures that the cabinet level immunity was having. Edward Holt has asserted that Dublin Castle was fully appraised of de Valera's whereabouts during this period :" When de Valera was using a doctor's house in Merrion Square as his supposedly a secret hide-out and he was there summoned to the telephone by a voice which coolly asked : "May I speak to Mr de Valera?'This is Alfred Cope, speaking from Dublin Castle."136

The immunity granted to de Valera by a British cabinet needs to be understood in the context of the relentless attacks being made on the police and army by the IRA. Just two weeks after Sturgis's articulated in his diary that the IRA, if treated with, could be converted into bribed men and therefore a bit under a British thumb, the RIC continued to face a murderous onslaught. In the British Army's $6^{\text {th }}$ Divisional Area in Ireland, one that covered the counties of Cork, Kerry and Limerick there were plenty of examples of this: "During the early days of February (1921),the RIC suffered severely in ambushes, the most disastrous of which took place at Dromkeen in Co Limerick on February $2^{\text {nd, }}$ when two Crossleys ${ }^{137}$ were ambushed and ten constables killed -all the wounded were dispatched in cold blood." ${ }^{138}$ During this same month Cope's attempts to establish contact with the leaders of the IRA continued. On $19^{\text {th }}$ February there was a raid on IRA Headquarters in South Frederick Street, Dublin. In epitome document no. 53/3649 on page two there is the following reference: "Michael Collins to C/S(Mulcahy) 19/2 /21.Cope-

\footnotetext{
${ }^{134}$ See N Macready ,Annals of an Active Life Vol II, London :Hutchinson,1924, p537.

${ }^{135}$ Minutes of Irish Situation Committee, $15^{\text {th }}$ June 1921, Lloyd George Papers F 25/1/42 House of Lords Library.

${ }^{136}$ E. Holt, Protest in Arms :The Irish Troubles 1916-1923,London :Putnam,1960 p247.

${ }^{137}$ Crossley Motors manufactured military vehicles between 1914-1945.The RIC and the British Army used them extensively in Ireland between 1920 and 1922.

${ }^{138}$ General Remarks on the Rebellion in the $6^{\text {th }}$ Divisional Area , p76,Strickland Papers IWM (
} 
Asking for instructions as to treatment of high RIC officials." ${ }^{139}$ This reference to high RIC officials by Collins showed a knowledge of the official post that Cope occupied ;being in charge of transport and correspondence branch of the RIC.

Winter's intelligence organisation was both locating and identifying Cope's activities with respect to the IRA. It is also worthy of note that Cope had access to the same intelligence that was being produced by the organised searches. Two days after this raid, on $21^{\text {st }}$ February, Sturgis recorded the following in his diary:" Andy on the telephone reported really good results from Dawson street raid. Another Shin HQ and useful documents seized -plans for ambushes and proof of their dissatisfaction with the results of those they've had recently in Dublin." 140

At the end of March the political context was operating began to change. Townshend has claimed that Bonar Law's retirement from the Government meant that there was now a greater flexibility in dealing with Sinn Fein ${ }^{141}$ As Sturgis recorded: "the PM is in a much more yielding mood and is prepared, not only to make big fiscal concessions but to take the initiative and say -of course after preliminary discussion into which the Ulster people will be brought- what price he is willing to pay for peace. ${ }^{142}$ " During this month British casualties continued to mount. In the third week there were 45 and in the last week of March there were 46. Despite these losses actionable intelligence was having an effect on the ability of the IRA to pace the insurgency. On the $24^{\text {th }}$ March a major arms dump was uncovered in Mountjoy Square. Just over a month later on $27^{\text {th }}$ April in some stables in Baggot Lane an IRA provincial weapons distribution centre was uncovered. ${ }^{143}$ Then on $29^{\text {th }}$ April an organised search on Blackhall Place captured 40 insurgents. Collin's own offices, the first in Mespil Rd and the secondly at 29 Mary Street had both been uncovered by the end of this month. Taken together these were substantial blows against the insurgency.

May 1921 was one of the most important months politically. The British Government was committed to hold elections to the Northern and Southern Ireland parliaments under the Government of Ireland Act. These elections even saw Lloyd George be willing to consider, " the question of

\footnotetext{
${ }^{139}$ Foulkes papers 7/24.Basil Liddell Hart Archives, King's College London.

${ }^{140}$ Sturgis Op Cit p130.

${ }^{141}$ Townshend op cit p174.

${ }^{142}$ Sturgis Op cit $\mathrm{p} 148$.

${ }^{143}$ For details see Townshend op cit p176.
} 
a truce during the elections in Ireland."144 This idea was rejected by the Cabinet. Yet in the same Cabinet discussion there is an insight to the quality of intelligence that was now being produced by organised searches, and the use that Hamar Greenwood, the Chief Secretary was willing to make of it: "The Sinn Fein Army -I attach its latest muster roll (a captured document )-is growing sullen, losing heavily and is certain to be defeated. A cessation now may mean its recovery....The position of the Crown Forces is stronger than it has ever been and is improving every day .The extremist leaders know this well and while they are prepared to fight on if there is no alternative" 145 . Yet he reassured the Prime Minister that Cope's channels of communication remained open:" We can get in touch with de Valera any day, indeed we keep in touch." ${ }^{146}$

Cope was also active with respect to the Ulster Unionists. Craig had secretly met de Valera on $5^{\text {th }}$ May. A meeting that had been arranged by Cope. It achieved very little in a practical sense. It was part of a tactic to portray the insurgency as a war between two groups of Irishmen. Cope kept up pressure for another meeting. Sir James Craig rejected these siren calls, and cited the impending elections to establish a parliament in the North of Ireland. On $14^{\text {th }}$ May the Chief Secretary sent the following communication to the Prime Minister: "Craig rightly refuses to meet De $\mathrm{V}$ again until after his election. But in the interval he has through my excellent Cope, who was in Belfast yesterday, submitted the attached suggested agenda for Dev's consideration". ${ }^{147}$

Cope continued to use Irishmen in Crown Service as a conduit for communications to the leaders of Sinn Fein. In a letter from Seamus O'Concubair to de Valera dated $18^{\text {th }}$ May, evidence is provided of Cope's willingness to disseminate operational intelligence with respect to the police. In addition, he had no compunction, despite being a civil servant , to openly question a key element of government policy, the Government of Ireland Act: "I went to see Lord Justice O'Connor on his invitation not knowing that Mr Cope would be present. The latter impressed me as an able man, very adroit and pretending a full appreciation of, and some sympathy with our point of view. He stated that arrangements were already made for the withdrawal of the Auxiliary Forces, presumably as a preliminary to a truce....he believed a settlement within the Empire,

\footnotetext{
${ }^{144}$ From the Secretary of the Cabinet to the Chief Secretary for Ireland ,11May 1921,F/19/4/91 Lloyd George Papers. House of Lords Library.

${ }^{145}$ Hamar Greenwood to the Prime Minister $11^{\text {th }}$ May,F/19/4/9,Lloyd George Papers, House of Lords Library .

${ }^{146}$ Ibid.

${ }^{147}$ Chief Secretary to the Prime Minister 14th. May 1921, F /19/4/ 9,Lloyd George Papers, House of Library/
} 
whether as a Republic within the Empire or a Commonwealth or by whatever name it might be called, would of course, have to be preceded by the scrapping of the present $\mathrm{Act}^{148}$. He referred contemptuously to the North -East Parliament as a Parliament that has smaller powers than an English County Council.".149

When the elections took place on $26^{\text {th }}$ May, Sinn Fein took an uncompromising approach: "Dail Eireann had decided to use the British election machinery as a cheap and convenient way of electing the Second Dail, which would be a larger assembly since the Government of Ireland Act provided for a lower house in Southern Ireland of 128 members ,as well as representation by 33 members in Westminster." 150 Sinn Fein were returned unopposed in all but the four seats, which had been allocated to Trinity College Dublin. As General Macready commented to Anderson, most those elected were 'leading gunmen and high officials in the IRA' ${ }^{\prime} 51$ This result did nothing to stop the insurgency or the casualties.

Townshend has calculated that from the beginning of May to the truce on $11^{\text {th }}$ July the RIC had 114 policemen killed and the British Army had 48 soldiers killed. ${ }^{152}$ Even Sturgis expressed his shock at the violence he was forced to bear witness to despite his endorsement of treating with the IRA. Most of all as an Englishman their lack of reciprocity shocked him : "Yesterday(Sunday $22^{\text {nd }}$ May) was uneventful save that these brutes took a poor devil they had wounded on Friday out of the Mater Hospital on a stretcher and shot him dead in the porch. If this is the sort of 'military operation' which is logical to expect to continue in spite of negotiations their mentality has me beat". ${ }^{153}$

During this month there was a progressive extension of the de facto legal immunity, already given to de Valera by the British Cabinet, to other leaders of the insurgency. Erskine Childers, the Sinn Fein Director of Publicity, was arrested along with Frank Gallagher on $9^{\text {th }}$ May 1921.Initially he was placed in an underground oubliette close to the Lower Castle Gate. He recounted in his diary an edited version of subsequent events and his interaction with Cope: "To my immense astonishment I was called for in an hour, taken to an officers' sitting room

\footnotetext{
${ }^{148}$ Cope meant the Government of Ireland Act which made provision for the setting up of two devolved parliaments in Dublin and Belfast.

${ }^{149}$ Seamus O' Concubair to Eamon de Valera, $18^{\text {th }}$ May 1921 , Documents on Irish Foreign Policy,

.Vol 1, 1919-1921, Dublin :Royal Irish Academy, 1998 p230-231.

${ }^{150}$ C.Younger, Ireland's Civil War, London :Fontana Books 1970 p149.

${ }^{151}$ Cited in Townshend p179. The breakdown was as follows:'30 internees, 22 in prison, 8 abroad,36 on the run,28 remainder 'from F/19/4/9/Lloyd George Papers ,House of Lords Library .

152 C. Townshed. Op Cit p185.

${ }^{153}$ Sturgis Op cit p181.
} 
and given a cup of tea. After a long wait in another room Alfred Cope came and told me I was to be released ....The disgust of the officers at the whole business was amusing, but Cope was adamant....I left the Castle myself ,Cope in his effusive manner and actually carrying my valise out of the gate for me!"154 Foy has claimed that Cope used this opportunity to leak to him documents for the Sinn Fein leadership. ${ }^{155}$ The effectiveness of Winter's surveillance and research operation was underlined again when the papers that Cope had slipped to Childers in his valise case were captured in an organised search and circulated by Winter to the relevant authorities in Dublin Castle. This was one of the few examples of Winter applying the third variable of counter-intelligence and attempting to neutralise Cope. This is confirmed by epitome No 5469. These documents were seized at 22 Mary Street in Dublin on $26^{\text {th }}$ May: "Erskine Childers to Minister of Finance(Collins) 16/5/21. Settlement outlined to me by Cope in the Castle a week ago was etc. He is probably a good actor, but his ostensible attitude was one of almost feverish anxiety to get something done and the business over ."156

Despite these efforts Cope's objective of a truce continued to be elusive. On the 24th May two days before the raid on Mary Street, the Irish Situation Committee met to examine the implications of extending martial law throughout the whole of Southern Ireland and considered what measures would have to be made for Crown Colony Government. Winter was by now fully aware that the government that he was working for was attempting to treat with the leaders of an insurgency that he was trying to defeat. In his autobiography he made reference to the cruellest of ironies. He was in receipt of intelligence that indicated the IRA was having difficulty in sustaining their campaign. Yet the police and the army were still subject to attacks. This all gave, "little satisfaction to the forces who were still waging war with the rebels, for in May 1921, the IRA Commander in the south wrote to Collins to say that owing to the shortage of arms and ammunition, his men would be unable to continue much longer." 157

The British government decided that if the devolved parliament in Dublin was not functioning within a fortnight of being summoned on the $28^{\text {th }}$ June then the Viceroy would dissolve it and declare martial law throughout Ireland, with the exception of Northern Ireland. Cope now had

\footnotetext{
${ }^{154}$ J.Ring ,Erskine Childers, London: John Murray, 1996p(check)

${ }^{155}$ Foy Op Cit p224.

${ }^{156}$ Foulkes Papers Op cit

${ }^{157}$ O. Winter, Winter's Tale,,London :The Richards Press ,1955 p341.
} 
imposed on him a deadline of $14^{\text {th }}$ July. With these pressures, Foy has claimed that, Cope leaked the Irish Situation Committee's recommendations to the leaders of the insurgency. ${ }^{158}$ To use Kent's phrase a 'meaningful pattern' can be discerned in another epitome that the Raid Bureau put into circulation. It contained a message from Collins to de Valera dated the $16^{\text {th }}$ June 1921: 'Reference to interview 'my man' who is very gloomy about the situation. Recites probable progress of events and foreshadows measures (correctly) to be taken if Martial law is enforced over the whole of Ireland." 159 Although it is impossible to say who 'my man' was ${ }^{160}$ Cope's leaking what were in effect cabinet papers was in one sense not surprising as he had been giving confidential and secret information to Sinn Fein since September 1920. ${ }^{161}$ The British government had progressively created a disconnect of governance. As Galula has argued this was the antithesis of a counter- insurgency strategy: "politics becomes an active instrument of operations, and so intricate is the interplay between them the political and the military actions that they cannot be widely separated; on the contrary, every military move has to be weighed with regard to its political effects, and vice versa". ${ }^{162}$

The Army by this time was cognisant of what Cope had been doing.Yet it did not detract from their determination to engage the IRA: "incredulous of the rumours that the Government were actually negotiating secretly with the leaders of the murder gang, everybody threw themselves with still greater energy into the struggle, and the campaign against the rebel Flying Columns was further intensified in June."163

If there was one event that symbolised the extent to which the British government had abandoned any semblance of an effective counterinsurgency strategy, it was the arrest of de Valera on $22^{\text {nd }}$ June. He was captured in an organised search by the Worcester Regiment, and initially did not give his correct name. ${ }^{164}$ The Foulkes papers provide evidence that when he was arrested he was found in possession of documents that linked him to an attack that had taken place on an army detachment seven days earlier: "de V is responsible for all acts of the IRA. As the head of the government for which it claims to act, it is true that he doesn't

\footnotetext{
${ }^{158}$ Foy Op Cit p228.

${ }^{159}$ Foulkes Papers 7/21 Basil Liddell Hart Archives ,King's College London.

${ }^{160}$ Foy claims it was Dwyer see Foy op cit p228.

${ }^{161}$ See 15.

162 D. Galula, Counter-Insurgency Warfare Theory and Practice, Westport :Praeger ,1964 p5.

${ }^{163}$ The Irish Rebellion in the $6^{\text {th }}$ Div Area from after 1916 rebellion to December 1921 ,Strickland Papers P363 IWM p112.

${ }^{164}$ See Jeune Papers IWM
} 
organise the actual atrocities but he has cognisance of them. Among his papers, when he was arrested last week (22/6/21) was the report, addressed to the President by the Minister of Defence on the train ambush near Dublin by the IRA against the R.W. Kent Regt (on the $16^{\text {th }}$ June)." 165 Sturgis referred to the 'seditious documents' found in his possession when he was arrested. ${ }^{166}$ Robert Jeune provides further evidence, from one of his former colleagues in the Special Branch Dublin Military District, of the extent to which the Cabinet's policy of de facto legal immunity for de Valera presented irreconcilable problems for the British intelligence community: "Now Jeffries told me that the following took place. Army G.H.Q.at Kilmainham wired to his London office 'De Valera captured. Cope suggests release.' This telegram arrived about 7p.m. and Jeffries took it across to the Colonial Office (Irish Office), but Hamar Greenwood had left, so Jeffries took it to Lloyd George, who rubbed his hands together and said 'Well done the military. He must on no account be released.' Taking this as settled, Jeffries left, but as soon as he had gone Lloyd George send orders for De Valera to be released, which was done." $" 167$

Winter, who happened to be in London at the time, requested an audience with the Prime Minister. When he enquired as to who ordered his release he was told by Lloyd George : "It was not on my orders that he was released." 168 Sturgis gave two further perspectives to this episode: first the inclination of policy makers to censor any media coverage of his arrest; secondly, Cope was involved in enforcing this secret policy: "Andy got on to the CS and Jonathan this morning ......they said de V was to be released at once and the fact that he was arrested at all was if possible to be kept out of the press". ${ }^{169}$

On $23^{\text {rd }}$ June, the day of de Valera's release, the Prime Minister summoned his key advisers to a cabinet meeting in London the following day. Cope although not initially invited, managed to gain access to the meeting due to the influence of Lady Greenwood. Sturgis nicknamed the meeting 'the Andy Cabinet'. It was to be Cope's first and last opportunity to address a full cabinet meeting. His political bias towards the insurgents resulted in a rebuke from his own Chief Secretary: "Andy harangued His Majesty's Ministers and even on his own showing must have been pretty hysterical.....he talked failure without an offer and Greenwood told him

\footnotetext{
${ }^{165}$ Foulkes Papers 7/24, Dublin 9/7/21, Basil Liddell Hart Archive, Kings College, London.

${ }^{166}$ Sturgis Op cit P?

${ }^{167}$ Jeune Papers IWM

${ }^{168}$ O. Winter, Winter's Tale, London: The Richards Press ,1955 p339.

${ }^{169}$ Sturgis Op cit p190.
} 
'to curb his Sinn Fein tendencies." ${ }^{170}$ The result was a personal letter from the Prime Minister to de Valera inviting him to meet him in London. ${ }^{171}$ Cope found a way to have this letter delivered on $25^{\text {th }}$ June 1921.

On the same day one of the most important secret agents the British state had in the upper echelons of Sinn Fein filed a report to Sir Basil Thompson, then Director of Intelligence in the Home Office. Foy has claimed that the identity of this agent was Molly Childers, the wife of Erskine Childers. ${ }^{172}$ If this was the case then she would have had access to the leadership of Sinn Fein including both de Valera and Collins. The latter had even made her a trustee of the Dail Loan! At the beginning of this report she commented on the de Valera's capture and subsequent folly of his release. But it is the judgement about his political attitudes that was instructive: "I have frequently told you that De Valera, what ever may be said to the contrary, is a red hot extremist." 173 . In contrast to Cope, she clearly had no illusions about the bankruptcy of a policy of negotiation, and upon whom the true cost of this policy would fall: "I must again emphasize what I have repeated time after time. Any thought of compromise or conciliation with SF is absolutely unthinkable and moreover is impossible. You are not only wasting your time, you are frittering away the lives of valuable and gallant servants of the Crown. ${ }^{\prime 174}$ She also had an acute sense of the absence of the one thing that Cope and his colleagues assumed in the leaders of Sinn Fein: some sense of reciprocity: "In our attempts at conciliation they see only weakness and signs that they are forcing the Government to its knees, to grant them any damn thing they want." 175

This intelligence report also gave a unique insight to three inter- related things: Cope's secret contacts and negotiations with the leaders of Sinn Fein were being reported on ; secondly his efforts were regarded by the leaders of Sinn Fein as nugatory in their utility; finally it underlined yet again the real efficacy of captured documents as a source of intelligence on the IRA: "I told you how negotiations carried on by Cope of the Castle had been scoffed at and ridiculed. They say there that he was primarily responsible for D.V.s release, and that Boyd (GOC Dublin District) was all for keeping him. Is this true? The Shinners have a great wind up over

\footnotetext{
${ }^{170}$ Idid p192.

${ }^{171}$ The full text of this letter can be found in Documents on Irish Foreign Policy, Vol 1,1919-1922

,Dublin ,Royal Irish Academy,1998 pp232-233.

${ }^{172}$ Foy Op Cit p234.

${ }^{173}$ Copy of Report from ----- dated 25.6.21,Lloyd George Papers, F/19/5/7,House of Lords Library.

${ }^{174}$ Ibid.

${ }^{175}$ Ibid
} 
some documents their august President had on him at the time of his arrest. Was anything valuable captured?"176

This intelligence report also gave an indication of her own declining motivation as a spy, which seemed to have crystallised around the issue of de Valera's release. She also made clear the real dangers she was running and the consequences for her if found out: "you know why I took this job on, not for cash but to feel that I was really doing something to help....I wouldn't get 10 minutes grace if they had the slightest suspicion....As you know very well, this work is of the most trying description, no shouting or even social life for that matter, apart from the Society of these Shinners. The war was a pleasure to this and one felt that everyone was out to win." ${ }^{" 177}$ This intelligence report was passed to Lloyd George by Hamar Greenwood on $29^{\text {th }}$ June. In the covering note to his secretary and mistress ${ }^{178}$ Greenwood characterised its importance in the following way: "My Dear Miss Stevenson,

This really comes 'straight from the Cow'179

HG

In one sense it was five days too late, as Lloyd George had already invited de Valera to London. However, this intelligence report left no illusions as to the nature of the people the Prime Minister had decided to negotiate with. de Valera's response to the Prime Minister's letter was given on the $29^{\text {th }}$ June and published in the press. Its tone disappointed even Cope, and Sturgis made a reference to de Valera's 'monkey house vanity'. ${ }^{180}$ The day before on $28^{\text {th }}$ of June, Anderson and Cope took a decision that was to have momentous consequences for Winter's intelligence organisation and its ability to record, collate, analyse and assess for action information with reference to Sinn Fein. It also included an ability to monitor Cope's relationship with the leaders of the insurgency. At a stroke it cut off a source that had provided $80 \%$ of their intelligence- organised searches: "In view of the fact, following the Prime Minister's letter, communications are likely to pass between leading Sinn Feiners which the government are bound to respect, no raids or searches must for the time being be made on premises occupied or frequented by persons of political importance without previous reference to this office (W. Cope or myself).Please give necessary instructions." 181

\footnotetext{
176 Ibid

${ }^{177}$ Ibid.

${ }^{178}$ Lloyd George had installed his mistress Miss Stevenson as his private secretary in Downing Street.

${ }^{179}$ Papers of Lloyd George, F19/5/7/ House of Lords library.

${ }^{180}$ Sturgis Op Cit p195.

${ }^{181}$ Memo from Sir John Anderson to Chief of Police June 1921,CO 904/188,National Archives.
} 
Two days later there was another extension of the scope of the policy of de facto legal immunity that had started with de Valera. The enforcement of law and the preservation of order had become increasingly a matter of political calculation. On $30^{\text {th }}$ June Cope insisted that Anderson sanction the release from Mountjoy prison of Griffith, MacNeill ,Duggan and Staines. Anderson, though in the dark himself, agreed to the release of all four convicted Republicans. On the same day Anderson wrote to his political boss the Chief Secretary. In this letter there was a written acknowledgement that Cope was acting far beyond his remit as a Crown civil servant: "The important thing now is to preserve the note of good will and reconciliation sounded in the Prime Minister's letter. Whatever may be the outcome this is clearly right. There are people on this side who would like to trick either DV or Craig into some false move which would shift public opinion now standing with the Gov to the other side. Cope is working for himself." 182

Lloyd George's letter of 25th June led eventually to a meeting in Dublin's Mansion House on $8^{\text {th }}$ July. General Macready the GOC met de Valera and other leaders of the insurgency to agree terms of a truce. This came into effect at 12 noon on $11^{\text {th }}$ July. It was preceded by: "one of the bloodiest weekends of the conflict, with the IRA killing some 20 people in 36 hours. The last shot was fired at a police patrol in Kingscourt ,Co Cavan, at 11.55am." ${ }^{183}$ Even Sturgis admitted to his diary that "they killed right up to the Armistice. ${ }^{184}$

\section{AFTER THE TRUCE}

There is a paradox with respect to Cope that is discernible after the truce. As previously stated, the ability of the intelligence community in Ireland to locate and identify his movements had disappeared completely. ${ }^{185}$ However, between September 1921 and March 1924 information came into the public domain which confirmed the veracity of the intelligence that the Raiding Bureau had obtained and had circulated through the epitomes. The source of the information was a series of statements and allegations made, on both on the floor of the House of Commons and the House of Lords, concerning Cope's actions prior to the truce.

\footnotetext{
${ }^{182}$ Letter from Sir John Anderson to the Chief Secretary of Ireland, 30th June 1921, F/19/5/8 Lloyd George PAPERS .House of Lords Library.,

183 Townshend Op Cit p198.

${ }^{184}$ Sturgis Op Cit p203.

${ }^{185}$ Hopkinson has claimed that from the $11^{\text {th }}$ of October, the start of the Anglo-Irish Conference, to its signing in the $6^{\text {th }}$ December 1921, John Anderson and Alfred Cope spent the bulk of their time in London involved in behind-the-scenes roles in the negotiations.
} 
In addition, after the truce the army emerges as a source of information with respect to Cope's actions. In August 1921 General Strickland sent the following message to army GHQ in Dublin: "The motor car restrictions are a farce. Republican leaders move freely without passes in stolen cars, a case occurred of a DIV Commander IRA being arrested for this offence by the RIC. His immediate release was ordered on the telephone by an Under -Secretary at Dublin Castle., who 'told off' the DI concerned for arresting him , and who chose to ignore my position as Military Governor of the Martial Law Area."186 In another confidential memo sent by the Colonel Commandant of the $17^{\text {th }}$ Infantry Brigade to General Strickland's $6^{\text {th }}$ Divisional Headquarters a similar pattern of wilfully undermining the rule of law can be discerned:" He (Cope )said that instructions would be sent for the car which the Essex Regiment took from the rebels to be handed back to the IRA. This car is the property of Colonel LUCAS of BALLINADEE, who is the sole and lawful owner of it, and it is difficult to know how its return to the rebels can be reconciled with any sense of justice and fair play". ${ }^{187}$ These two examples illustrated the extent to which Cope continued as Anderson had expressed it 'working for himself.'

Ironically it was the House of Commons that supplied an answer to the question that had been originally posed by Captain Robert Jeune in September 1920. Why was Cope one of the very few British officials who could walk safely about the streets of Dublin.? ${ }^{188}$ The Unionist MP for Belfast Woodvale, Robert Lynn ${ }^{189}$ delivered the answer when he posed the following question to the Chief Secretary: "whether any high official in Dublin Castle was supplied with a safe permit or pass by the Irish republican army or Sinn Fein, and under what conditions it was issued" ${ }^{190}$ Greenwood refuted the first part of the question and then claimed that the second part did not arise. Lynn then responded with a supplementary question :"How is it that Mr Cope was able to go about Dublin?"191 Greenwood's feeble riposte was to describe Cope as a 'plucky servant of the Crown'. There was a more serious allegation made by Lynn: "whether key ciphers and confidential information regarding important matters in Ireland have been communicated by high officials in Dublin Castle to Sinn Fein Leaders; whether careful investigations have

\footnotetext{
${ }^{186}$ General Strickland to Army GHQ Dublin, 22/8/ 1921,Strickland Papers, P363 IWM.

${ }^{187}$ Confidential memo No 26.Visit of Mr Cope ,Assistant Under Secretary at Dublin Castle to Bandon $15^{\text {th }}$ September 1921,Strickland Papers P363, Imperial War Museum.

188 See 16.

${ }^{189}$ He was MP for Woodvale between 1918 and 1922 and MP for West Belfast between 1922 and 1929.

${ }^{190}$ Parliamentary Debates, Commons Vol 147 Col 1900, $3^{\text {rd }}$ November 1921.

191 Ibid.
} 
revealed the fact that not more than three officials could have been responsible for betraying the Government secrets" ${ }^{" 192}$ Given the fact that Cope was in charge of the transport and communications branch of the RIC, he was the prime suspect. His final question to Greenwood revealed the consequences of Cope's actions: "whether it is a fact that on several occasions when the police have made searches they have found the secret key cypher before it has been communicated to the county inspector." 193 The Chief Secretary maintained that he had no knowledge of these facts. Lynn simply responded that he had. ${ }^{194}$

Three years later in 1924 the Irish peer, Lord Muskerry made another set of allegations against Cope. The context for this was the ongoing claims for compensation by 'Irish Loyalists' for attacks launched against their property by the IRA during the insurgency. The date of the attack against Lord Muskerry's property was on 4th July 1921: "My place was entered by an armed gang of Sinn Feiners who, after removing the servants under arrest, proceeded to spread the contents of a barrel of petroleum over the furniture and floor. They then set fire to it. The place was entirely consumed with a valuable collection of old Family portraits and other paintings, old Jacobean furniture, china and other valuables."195

Having given the details of the attack, he then without using his name referred to Cope's his previous career details and the fact that he had been appointed on the personal authority of Lloyd George: "He selected a certain person in the service of the Excise Department..... This person was sent over to Ireland as an Assistant Under Secretary. Mr Lloyd George also sent over four other officials, but I am dealing especially with this Assistant Under Secretary. ${ }^{196 " ~ L o r d ~ M u s k e r r y ~ d i r e c t l y ~ q u e s t i o n e d ~}$ whether Cope had acted merely as a Crown civil servant carrying out the instructions of his political masters: "On his arrival at the castle he took advantage of his official position to attend meetings held by heads of Departments to consider the best means of putting down these outrages and of restoring law and order. Having obtained full information, he at once proceeded to convey that information to the leaders of the Sinn Fein organisation, with the result that these plans devised by His Majesty's officers came to naught and in many cases His Majesty's officers and men lost their lives. The result of this treachery at headquarters was to

\footnotetext{
192 Ibid. Col 1902.

${ }^{193}$ Ibid Col 1902

${ }^{194}$ Ibid Col 1902.

${ }^{195}$ Hansard House of Lords, $5^{\text {th }}$ March 1924 Vol 56 Col 535.

196 Ibid Col 536.
} 
paralyse the efforts of His Majesty's officials, and crime and outrage were rampant throughout the country." 197

A response to Lord Muskerry's claims was not long in coming. On $19^{\text {th }}$ March 1924, Viscount Fitzalan of Derwent, a former Lord -Lieutenant of Ireland, addressed the House of Lords and proceeded to defend Cope and his actions. His only concession was to admit he had been a :" liaison officer on behalf of the Government with the Sinn Fein people." ${ }^{198} \mathrm{He}$ also quoted a letter he had received from General Macready, the former GOC for Ireland. The General claimed :"never did I hear the breath of suspicion of disloyalty. Had such been suspected it would certainly have come to my ears." 199 Viscount Fitzalan then challenged Lord Muskerry to substantiate the charges he had made on the floor of the House of Lords, or to repeat them outside the House and let the law take its course.

Lord Muskerry's initial response, not surprisingly was to protect his sources: "I had the news from friends whom I knew, and who were in a position to speak, and it is their statement that I made". ${ }^{200}$ In the two weeks between his initial statement in the House of Lords and this subsequent debate Lord Muskerry added weight to his allegations by citing the corroborating evidence he had recently received: "Since that debate I have received a number of letters from officers and ex-officers of the Royal Irish Constabulary who were in Dublin at the time, and they make the same statement. These letters are marked private and confidential , and I cannot make use of them."201

This Irish peer went so far as to suggest that the government set up a committee with the power to investigate Cope's actions and take evidence as to what happened between 1919 and 1921. This proposal was rejected by the Lord Chancellor. Instead Cope was defended: "The Government are thoroughly satisfied that no case has been shown to make Sir Alfred Cope deserving of reproach." ${ }^{202}$ It was also claimed that he had acted with the full knowledge of the Chief Secretary and the Under Secretary. The Lord Chancellor was supported by Lord Curzon who demanded that Lord Muskerry withdraw his original statement. This eventually he was forced to do. ${ }^{203}$

\footnotetext{
${ }^{197}$ Ibid Col 537.

${ }^{198}$ Hansard ,House of Lords, $19^{\text {th }}$ March 1924 Vol 56, Col 915.

199 Idid Col 920.

200 Ibid Col 922.

201 Ibid Col 924.

202 Ibid Col 924.

${ }^{203}$ Ibid Col 926.
} 


\section{CONCLUSIONS}

The concepts of counter-intelligence have been used in this article to identify the patterns and casual mechanisms that could both trace and explain Cope's behaviour and to provide some answers to two questions. First, to what extent did he systematically pass confidential and secret information to the leaders of the insurgency? Secondly, how far did he facilitate the granting of a progressive de facto legal immunity to the leadership of Sinn Fein?

With respect to the former question there is clear evidence to suggest that Cope within months of taking up his post in Ireland was passing confidential and secret information to Sinn Fein. There is evidence to suggest that members of the RIC lost their lives as a result of his actions. In addition, he had no compunction about undermining the rule of law in favour of what he interpreted as political expediency. This raises another question about his motivation to behave in the way that he did? Any answer to this question will be speculative. Not surprisingly Cope left no private papers. When Cope arrived in Ireland his political beliefs, self government for Ireland, were already formed as General Macready has indicated. ${ }^{204}$ More importantly this posting gave him a career opportunity that otherwise would have been closed to him.

In terms of social class in 1920s Britain, Cope's appointment was unusual in comparison to the background of his peers. When W.E. Wylie, the law adviser in Dublin Castle, asked Sturgis how it was that he Anderson and Cope had arrived together in such high positions, Sturgis responded with a metaphor which summarised the social differences aptly:"Anderson came in through the front door, Cope via the back door and himself through the drawing -room window". ${ }^{205}$ Sturgis described him in a manner that indicated a lack of familiarity with someone like Cope, 'a most interesting unique creature and was at one time an Excise Detective.' In one sense Cope's background was an advantage. He was able to mix with the predominantly lower middle class, and working class leaders of Sinn Fein with an ease that Sturgis, with an Eton and Oxford background, would have been unable and unwilling to do. Yet his background resulted in him rejecting the restrictions that inevitably applied to senior Crown civil servants. For Sturgis this boiled over a month after the Truce in August 1921. At the Royal Dublin Horseshow Cope avoided the Royal box where most of the senior Castle officials gathered. Instead he flaunted relationships that had until very recently

\footnotetext{
${ }^{204}$ See p13.

${ }^{205}$ Quoted in M. Hopkinson ,The Last Days of Dublin Castle, Cork: Irish Academic Press 1999 p6.
} 
been kept secret, "he goes 'down the drain' not only for business but for pleasure, spends most of his evenings with Shinns of various sorts and seems to dislike all other society. They remember, if he seems to forget sometimes, that he is a highly placed British official with much of the dignity of England in his hands and I worry sometimes that his sympathy will encourage them to think they can get through him all they ask. ${ }^{206}$ ",

In terms of the latter question we are presented with a paradox. The decision to grant de facto legal immunity to de Valera and then its progressive extension was not something that was in Cope's gift. As Sir John Anderson had indicated, it was a cabinet level decision initially. Cope merely extended when he judged it appropriate. Yet as Anderson had remarked to Greenwood by June 1921 Cope was 'working for himself.' However, there is one dimension of his relations with the government of the day that remains an enigma-his relationship with Lloyd George. Sturgis suggests in his diary that the Prime Minister had a preference for a 'bad bargain in five minutes rather than a good one in two hours'. In addition, the impression that Cope conveyed to leaders of the insurgency like Childers was one of 'feverish anxiety to get something done and the business over'. As Captain Robert Jeune discovered his treasonable acts were protected at a highest level of government.

However, it has not been possible to locate evidence of direct communication between Cope and Lloyd George. However, it is worthy of note that in the same month that he finally left Ireland, October 1922, he was knighted and became Sir Alfred Cope. An honour conferred on him by Lloyd George. Ironically he never held another post in the civil service when he came back from Ireland. From 1923 to 1925 he occupied the post of secretary of the National Liberal Party. Yet the politician he had served from afar brought fresh problems for Cope: "he found close co-operation with Lloyd George impossible, and abandoned politics altogether." ${ }^{207}$ There is no doubt that Cope's secret relationship with the leaders of the insurgency directly led to a decision by the British Government to agree to a truce in July 1921.Confirmation is provided by Sturgis: "Lady Greenwood asked me this morning in mockery -'Who has made the Truce -Smuts or the Viceroy'? 'Neither ' says I ,'but one Cope. ${ }^{208}$ "

\footnotetext{
${ }^{206}$ Sturgis Op Cit p213.

${ }^{207}$ Dictionary of National Biography 1951-1960 ,Oxford :Oxford University Press ,1971,p252.

${ }^{208}$ Sturgis Op cit p201.
} 
One of the by products of examining Cope activities through the prism of counter-intelligence is that it is possible to address an important and related question that was raised at the beginning of this article. Can we now reassess the quality and the effectiveness of the new intelligence organisations that were established from June 1920 onwards ? ${ }^{209}$ Kent identified two important functions that were vital to counter-intelligence: surveillance and research. Winter in his final report provided an insight to these concepts as they related to the campaign that he had just fought.

The most contentious issue with respect to surveillance and research was the duplication of effort between the army and the police. Winter argued that this was a price worth paying to maintain efficiency, and that the Local Intelligence Centres were in the process of resolving this issue "It is better to waste a certain amount of energy and time in duplication than to incur a loss in efficiency, and this opinion has been endorsed by the large majority of Police officers concerned. As has been inevitable delays interfered with the purposes and gradual development of the Intelligence organisation but, with the establishment of Local Centres, a marked improvement resulted, and would have continued, had not the political situation brought to an end." ${ }^{210}$ Winter also took a more nuanced approach, at the operational level, to the primacy of the RIC and their Special Branch than he has been given credit for ${ }^{211}$ :"The psychology of the Crimes Special Sergeant had to be taken into consideration. He was an Irishman, and even to Police Officers of long service, his confidence was given with circumspection."212

Moreover, Winter understood that intelligence was not a panacea with respect to insurgency:" Intelligence alone cannot win a war. It is merely an aid to force, and it is only by action that the desired end can be attained. ${ }^{213} \mathrm{He}$ also claimed that the British government used a degree of 'coercion which was not sufficiently severe.' Although he stated that they nearly succeeded. He identified a cardinal weakness in the policy makers approach and related it back to one of the leading theorists of war: "The great Clausewitz said 'All kinds of philanthropy in war are a gross and pernicious error" 214 .

\footnotetext{
209 p3.

${ }^{210}$ A Report on the Intelligence Branch of the Chief of Police from May 1920 to July 1921. National Archives CO 904/156 B.p69.

${ }^{211}$ See British Intelligence in Ireland 1920 -1921 (ed P.Hart ) Cork :Cork University Press ,2002 p14.

${ }^{212}$ A Report on the Intelligence Branch of the Chief of Police from May 1920 to July 1921. National Archives CO 904/156 B p68.

213 Ibid p73.

214 Ibid p74.
} 
At the beginning of this article Foy made the point that many of the problems that intelligence officers had to deal with were caused by politicians ${ }^{215}$.Hart concurred with this assertion: "intelligence efforts were continuously affected (and deflected) by shifts in policy, usually with the aim of conciliating nationalist opinion". ${ }^{216}$ It can be suggested that these shifts in policy had a number of implications that affected the tenor of the whole campaign.

First the need to challenge, at the strategic level, the narrative of Irish Republicanism was never consistently addressed. This is underlined in the last paragraph of the British Army's official two volume report into the campaign :'In one department, however, which apparently was independent of the Director of Intelligence, namely Publicity it was unrivalled .This department was energetic, subtle, and exceptionally skilful in mixing truth falsehood and exaggeration and was perhaps the most powerful and the least fought arm of the Sinn Fein Forces."217

Secondly, senior army officers such as General Strickland ${ }^{218}$ were by the end of the campaign deeply despondent and disillusioned at what they had witnessed as the disconnected approach of the government he had served in Ireland for over two years. The last entry in his Irish Command diary dated $17^{\text {th }}$ May $1922{ }^{219}$ summed it all up: "And so this is the end of two and half years toil. A year ago(May 1921) we had a perfect organisation and had 'them' beat. A short time more would have completed it thoroughly. 'They' knew this .and got the -Politicians to negotiate with the present results. Never has the country been in such a state . No sort of order or authority in these parts. All our labours and energy have been thrown in the gutter ,to say nothing of the expense and the deprivation. It almost makes one wish one had never been concerned in the show." 220

The final insight to the manner in which the campaign was affected by Cope's secret activity comes ironically from Cope himself. ${ }^{221}$ It revealed that not just shifts in policy as Foy and Hart have claimed, but a systematic effort to portray the character and outcome of the insurgency in a particular way that has been highly pervasive. In 1951, three years

\footnotetext{
${ }^{215}$ See $\mathrm{p} 4$.

${ }^{216}$ Hart op cit p15.

${ }^{217}$ Intelligence in Ireland ,1920-1921, vol 2 p46, Strickland Papers IWM P325.

218 General Strickland 1869-1951. He was the Commanding Officer for $6^{\text {th }}$ Division from 1919 to

1922.This area covered Cork and West Cork areas of intense insurgent activity.

${ }^{219} \mathrm{He}$ was ordered out of Ireland on $18^{\text {th }}$ May 1922.

${ }^{220}$ Strickland Papers,P363 Pocket Diary p5 IWM

${ }^{221}$ Cope left behind no personal papers.
} 
before his death he was invited by the Private Secretary of the then Irish ambassador to the United Kingdom, Mr Dulanty to participate in an oral history project that it had decided to set up. This programme was called the Bureau of Military History. ${ }^{222}$ It had been established in January 1947 by the then Irish Minister of Defence, Oscar Traynor. ${ }^{223}$

Cope, perhaps not surprisingly, refused to participate in the project. Yet in giving his reasons we get a sense of both justification and remorse about the events he helped shape: "Over the years I have had offers from various sources for my views and experiences but have turned then all down because I regard the period (and also that following the Treaty) to be the most discreditable of your country's history-it is preferable to forget it :to let sleeping dogs lie." ${ }^{224}$ Secondly, he provided a unique critique of the narrative that he himself had done so much to construct: "The I.R.A. must be shown as national heroes and the British Forces as brutal oppressors. Accordingly, The Truce and the Treaty will have been brought about by the valour of small and ill- equipped groups of irregulars. And so on. What a travesty it will be and must be."225 Cope's letter also acknowledged the self sustaining destructiveness of what would become the accepted Irish Republican narrative : "Read by future generations of Irish children, it will simply perpetuate the long standing hatred of England and continue the work of self-seeking politicians."226. Events in Ireland between 1919 and 1922 are still set within this judgement that still dominates today: "The dominant narrative remains that of the nationalist movement in conflict with British rule." ${ }^{227}$ In addition, there is the belief that the British side failed to provide and sustain coherence: "It might be argued that the IRA campaign succeeded largely through the lack of political direction on the British side." ${ }^{228}$ The accepted judgement about the effectiveness of British intelligence, both its organisation and its end product, needs to be understood in the context of Cope's activities that hampered both.

\footnotetext{
${ }^{222}$ The objective of the Bureau was 'to assemble and co-ordinate material to form the basis for the compilation of the history of the movement for independence from the formation of the Irish Volunteers on $25^{\text {th }}$ November 1913 to the signing of the Truce on $11^{\text {th }}$ July 1921'. The creation of the Bureau was approved by the then Irish Prime minister, Eamon de Valera. The work of the Bureau was completed in 1957.All the assembled material was then kept under lock and key in the basement of the Department of the Taosoich for 45 years when it was released in 2002.

223 Traynor ran the Dublin Brigade of the IRA between 1919 and 1921.

${ }^{224}$ Letter from A. Cope to the Private Secretary to Mr Dulanty $3^{\text {rd }}$ January 1951,Bureau of Military History, Cathal Brugha Barracks ,Dublin.

${ }^{225}$ Ibid.

226 Ibid.

${ }^{227}$ P. Hart ,The IRA at War 1916-1923,Oxford :Oxford University Press, 2003 p8.

${ }^{228}$ F.W.Beckett, Modern Insurgencies and Counter -Insurgencies, London Routledge ,2001 p
} 
There is also the issue of understanding this campaign in the wider context of why an insurgency is something that no state can ignore, let alone treat with, and identifying the key problem that the state has to successfully address. It is also important to consider British attitudes to counter-insurgency. Beatrice Heuser identified the nature of the threat posed, "Insurgents threaten the very power structure of society." 229 She has also identified the key challenge in countering any insurgency, "The most immediate and pressing problem of counterinsurgency has always been how to find and capture the insurgents." 230 The willingness to grant de fact legal immunity to de Valera, and a reluctance to action intelligence that Winter had obtained about Collins whereabouts underlined the disconnected nature of the British approach.

Colin Gray has argued that strategic culture is not only 'out here', but 'within us' .Individuals, institutions, and collective behaviour form an important context. It weaves together through people and institutions and encompasses ideas and norms. The British political class has displayed a perverse approach to insurgency: "Secret negotiations, it must be remembered, are a constant trend throughout British counter-insurgency campaigns". ${ }^{231}$ Cope certainly exemplified this proclivity in Ireland between 1920 and 1921.This preference it can be argued is part of a wider cultural context that goes beyond the narrow confines of unconventional war. Basil Liddell Hart has claimed that there is a hidden British cultural assumption with respect to war: "A romantic habit has led us to hide, and has even hidden from us, our essentially business like traditions in the conduct of war." 232 This goes some way to explain why the cause indentified by the Royal Commission in the run up to the 1916 Irish rebellion: the cardinal rule of Government demands that enforcement of law and preservation of order should always be independent of political expediency continued with no change between 1919 to 1921. Alexander would argue that it represented the existence of what he termed an 'operating code'. It expresses a political leader's and policy makers beliefs about the nature of politics and conflict. Collectively they act as a:"prism that influences the actors perceptions and diagnoses of the flow of political events, his definitions and estimates of particular situations." 233

\footnotetext{
${ }^{229}$ B. Heuser, The Evolution of Strategy, Cambridge: Cambridge University Press, 2010 p 419.

${ }^{230}$ Ibid p 425.

${ }^{231}$ A. Mumford, The Counter -Insurgency Myth: Oxford ;Routledge 2012,p102.

${ }^{232}$ B. Liddell Hart, The British Way in Warfare, London :Penguin Books 1947.p29.

${ }^{233}$ A.L. Alexander, The Operational Code :A Neglected Approach to the Study of Political Leaders and Decision Making, International Studies Quarterly Vol 13,No 2 ,June 1969 p191.
} 
Finally in a normative sense the relationship between an intelligence community and a state is an important one. Smith has argued: "If we see intelligence and security as a part of the core executive machinery then we can analyse intelligence in terms of its role in the political relationship with central government. "234 The relationship that the intelligence community in Ireland had with both the administration in Dublin Castle and Lloyd George in London was a disconnected one. Despite this in a very short period of time British intelligence succeeded in two respects: at a tactical level it identified the insurgents and produced actionable intelligence. This in turn challenged the ability of the IRA to pace the conflict. At the operational level intelligence enabled the security forces to penetrate, divert and subvert the IRA's organisational networks. In any counterinsurgency intelligence is in the forefront of both police and military operations. Often the border between them can be hard to discern. In Ireland between 1919 and 1921 Cope's activities undermined the legal authority of the British state and the competent execution of rational rules. Yet the concepts of counter-intelligence have helped us understand why and how he was able to act in the ways that he did.

${ }^{234}$ M.J. Smith, Intelligence and the Core Executive, Public Policy and Administration Vol ? No ? (to be finished) 